\title{
Simulation of semi-arid biomass plantations and irrigation using the WRF-NOAH model - a comparison with observations from Israel
}

\author{
O. Branch ${ }^{1}$, K. Warrach-Sagi ${ }^{1}$, V. Wulfmeyer ${ }^{1}$, and S. Cohen ${ }^{2}$ \\ ${ }^{1}$ Institute of Physics and Meteorology, University of Hohenheim, Stuttgart, Germany \\ ${ }^{2}$ Institute of Soil, Water and Environmental Sciences, Agricultural Research Organization, Volcani Center, Bet-Dagan, Israel \\ Correspondence to: O. Branch (oliver_branch@uni.hohenheim.de), K. Warrach-Sagi \\ (kirsten.warrach-sagi@uni-hohenheim.de),V.Wulfmeyer (volker.wulfmeyer@uni-hohenheim.de), and S. Cohen \\ (vwshep@volcani.agri.gov.il)
}

Received: 27 September 2013 - Published in Hydrol. Earth Syst. Sci. Discuss.: 15 November 2013

Revised: 11 March 2014 - Accepted: 12 March 2014 - Published: 15 May 2014

\begin{abstract}
A $10 \times 10 \mathrm{~km}$ irrigated biomass plantation was simulated in an arid region of Israel to simulate diurnal energy balances during the summer of 2012 (JJA). The goal is to examine daytime horizontal flux gradients between plantation and desert. Simulations were carried out within the coupled WRF-NOAH atmosphere/land surface model. MODIS land surface data was adjusted by prescribing tailored land surface and soil/plant parameters, and by adding a controllable sub-surface irrigation scheme to NOAH. Two model cases studies were compared - Impact and Control. Impact simulates the irrigated plantation. Control simulates the existing land surface, where the predominant land surface is bare desert soil. Central to the study is parameter validation against land surface observations from a desert site and from a 400 ha Simmondsia chinensis (jojoba) plantation. Control was validated with desert observations, and Impact with Jojoba observations. Model evapotranspiration was validated with two Penman-Monteith estimates based on the observations.

Control simulates daytime desert conditions with a maximum deviation for surface $2 \mathrm{~m}$ air temperatures $(T 2)$ of $0.2^{\circ} \mathrm{C}$, vapour pressure deficit (VPD) of $0.25 \mathrm{hPa}$, wind speed $(U)$ of $0.5 \mathrm{~m} \mathrm{~s}^{-1}$, surface radiation $\left(R_{\mathrm{n}}\right)$ of $25 \mathrm{~W} \mathrm{~m}^{-2}$, soil heat flux $(G)$ of $30 \mathrm{~W} \mathrm{~m}^{-2}$ and $5 \mathrm{~cm}$ soil temperatures (ST5) of $1.5^{\circ} \mathrm{C}$. Impact simulates irrigated vegetation conditions with a maximum deviation for $T 2$ of $1-1.5^{\circ} \mathrm{C}$, VPD of $0.5 \mathrm{hPa}, U$ of $0.5 \mathrm{~m} \mathrm{~s}^{-1}, R_{\mathrm{n}}$ of $50 \mathrm{~W} \mathrm{~m}^{-5}, G$ of $40 \mathrm{~W} \mathrm{~m}^{-2}$ and ST5 of $2{ }^{\circ} \mathrm{C}$. Latent heat curves in Impact correspond closely with Penman-Monteith estimates, and magnitudes of $160 \mathrm{~W} \mathrm{~m}^{-2}$ over the plantation are usual. Sensible
\end{abstract}

heat fluxes, are around $450 \mathrm{~W} \mathrm{~m}^{-2}$ and are at least 100 $110 \mathrm{~W} \mathrm{~m}^{-2}$ higher than the surrounding desert. This surplus is driven by reduced albedo and high surface resistance, and demonstrates that high evaporation rates may not occur over Jojoba if irrigation is optimized. Furthermore, increased daytime $T 2$ over plantations highlight the need for hourly as well as daily mean statistics. Daily mean statistics alone may imply an overall cooling effect due to surplus nocturnal cooling, when in fact a daytime warming effect is observed.

\section{Introduction}

The large-scale implementation of biomass plantations in arid regions is the subject of recent research due to the perceived potential for carbon sequestration, energy production, agricultural development and environmental services (Becker et al., 2013; Beringer et al., 2011). Such plantations are becoming feasible through modern desalination (Khawaji et al., 2008; Fritzmann et al., 2007), wastewater (Hamilton et al., 2007; Oron et al., 1999), and irrigation techniques (e.g., see Spreer et al. 2007). Valuable and hardy shrubs such as Jatropha curcas (jatropha) or Simmondsia chinensis (jojoba) can withstand heat and drought, and be irrigated with waste- or brackish water (Rajaona et al., 2012; Abou Kheira and Atta, 2009; Benzioni, 1995). These traits makes them more viable than many food crops and may reduce threats to food security if exclusive use of marginal land is adhered to (Becker et al., 2013). 
Critical research is still missing however, on potential climatic impacts caused by significant land surface modifications in arid regions. Vital insights can be obtained using dynamically-downscaled simulations with coupled atmospheric/land surface models. Such models need careful calibration for regional arid conditions though, and validation to assess confidence in simulation results.

Large-scale agroforestry (AF) could modify the local and regional climate. Alpert and Mandel (1986), observed a reduction in amplitude and variance of wind speeds $(U)$ and $2 \mathrm{~m}$ temperatures (T2) in Israel over three decades. They correlated changes with increases in irrigation since the 1960s, and attribute them to lower sensible heat fluxes (HFX) and changes in albedo and roughness. De Ridder and Gallé (1998) concurred with these trends. Increases in rainfall, especially around October were also found by Ben-Gai et al. (1998, 1994, 1993) and Otterman et al. (1990) (in Perlin and Alpert, 2001). This is likely due to the combination of autumn climatic conditions and the land surface perturbations. From De Ridder and Gallée (1998), Alpert and Mandel conclude that altered weather patterns are caused by lower HFX from irrigated cops, whereas Otterman cites increased HFX from non-irrigated shrubs. For the latter land use type, higher HFX and lower latent heat (LH) magnitudes would result from less water availability. Otterman (1989) also found that increased Saharan fringe vegetation increased daytime convection and atmospheric boundary layer (ABL) growth.

Given the likely dependence of flux partitioning on soil moisture, this presents some interesting questions to investigate: what partitioning of fluxes can be expected from a large arid irrigated plantation? How would these fluxes contrast with the surrounding desert surface?

The introduction of large vegetation patches into deserts is likely to induce significant horizontal flux gradients, increase surface roughness, moisten the ABL, modify turbulent flows, and induce pressure perturbations. These phenomena would influence ABL evolution and may cause convergences (Wulfmeyer et al., 2014) and mesoscale circulations (Hong, 1995; Mahfouf et al., 1987). Impacts could be dependent on the scale of the patches. Dalu et al. (1996) suggest flux gradients of the order of 1 to $10 \mathrm{~km}$ are sufficient to induce significant changes. Letzel and Raasch (2003) estimate scales of around $5 \mathrm{~km}$ from large eddy simulations (LES). Contiguous plantations on scales of this order could be feasible now for the reasons previously discussed.

Regarding fluxes, an expectation is that a freely transpiring canopy would result in low HFX and higher LH, in contrast to bare desert surfaces where LH is likely to be almost zero. However, it is not clear how plantation HFX magnitudes would compare with typically high desert HFX. Firstly, there is generally a greater surface net radiation $\left(R_{\mathrm{n}}\right)$ at canopy surfaces due to lower albedos. Secondly, leaves can be very efficient heat radiators, and have lower heat storage potential than most substrates (Warner, 2006). Finally, desert crops such as jojoba or jatropha may not transpire freely due to their high water use efficiency and resistance to water stress (Silva et al., 2010; Abou Kheira and Atta, 2009; Benzioni and Dunstone, 1988) and also because efficient irrigation techniques such as partial root zone drying are used (Spreer et al., 2007). The final point is significant, because in arid regions a fine balance exists between maintaining yield and plant health, and the need to conserve water. Plantation evapotranspiration (ET) could therefore be limited, resulting in higher HFX magnitudes than a freely transpiring canopy implies. An example of large HFX magnitudes from drier vegetation is the Yatir pine forest in Israel, where Rotenberg and Yakir (2010) observed summer HFX magnitudes that were 1.3 times higher than over the Sahara and 1.6 and 2.4 times higher than tropical and temperate forests, respectively.

Relative HFX over plantation and desert will depend largely on the albedos and energy balance over the plantation. In turn, albedo generally depends on crop type, phenological stage, leaf area index (LAI), canopy cover, senescent material and so forth (e.g. Ingwersen et al., 2011; Zhang et al., 2013). ET and upward turbulent transport of moisture depends not only on available energy, water availability, soil characteristics and boundary layer conditions, but also on roughness and plantation/canopy/leaf homogeneity, geometry and scales (Bonan, 2008; Burt, 2002; Raupach and Finnegan, 1996). Specific plant characteristics and survival strategies also play a major role, such as modified reflectivity, photosynthesis pathways or stomatal closure. These characteristics are observed in many desert species (Warner, 2006), such as jojoba (Seventh International Conference on Jojoba and its uses: Proceedings, 1988) and Jatropha curcas (Silva et al., 2010).

In order to estimate impacts on atmospheric interactions, detailed simulations are carried out within coupled atmospheric and land surface models (LSM). This can be achieved by artificially modifying the land surface data used by the LSM to calculate surface exchanges. If the irrigated vegetation surface is correctly parameterized, we can then go on to assess the impacts on (a) diurnal fluxes, (b) feedbacks to and from the ABL, and (c) mesoscale impacts such as convection initiation. Furthermore, the effects of variables such as plantation size and location on these phenomena, can be explored.

The use of coupled 3-D models is preferable to the use of uncoupled models, where a land surface model is forced unidirectionally with atmospheric forcing data. This is because uncoupled models neglect the simultaneous feedbacks which occur between the surface, boundary layer and entrainment zone. These processes are central to ABL evolution (see, e.g. Van Heerwaarden et al., 2009), evaporation and therefore flux gradients over heterogeneous landscapes. The use of fine resolutions of e.g., less than $4 \mathrm{~km}$, allows for detailed resolution of landscape features and can reduce systematic errors and biases in soil-cloud-precipitation feedbacks commonly seen in coarser models where convection is normally parameterized (Rotach et al., 2009, 2010; Wulfmeyer et al., 2008, 
2011; Bauer et al., 2011; Weusthoff et al., 2010; Schwitalla et al., 2008).

Our ultimate goal is to use the WRF-NOAH model to conduct impact studies on meso- $\alpha$ scales. This study focuses on the parameterization and validation of the WRF (Skamarock et al., 2008) with its LSM NOAH (Chen and Dudhia, 2001) model for the region/vegetation/irrigation/soils, and also on the comparison of energy fluxes over the desert and plantation. Two model scenarios are set up - WRF Control and WRF Impact. WRF Control represents a baseline, using unmodified MODIS land surface type initialization data and the second is a simulation of a $10 \times 10 \mathrm{~km}$ irrigated plantation (WRF Impact). WRF Control output is compared to observations from a desert surface and WRF Impact is compared with observations from the jojoba plantation. These observations were collected especially for the experiment. Specific objectives are

- to conduct an experimental study, to form the basis for a model configuration for later impact studies on largescale arid plantations;

- to build and set up a WRF-NOAH model simulation for irrigated plantations in a semi-arid region;

- to verify the model for follow-up impact studies.

In Sect. 2, the study area in Israel is described, including climate, and specifics on the irrigated plantations and surrounding area. In Sect. 3, the field methodology and observation data from desert and plantations are presented. In Sect. 4, the methodology for the WRF-NOAH model simulations are covered, including configuration, domains, and the simulation of irrigated vegetation. In Sect. 5, WRF-NOAH simulations are compared with field observations, including calculated evapotranspiration. Finally the results are discussed in Sect. 6.

\section{The study area and its climate}

The impact of plantations is studied in the semi-arid region of Israel. In this area, long hot summers, clear skies and high radiation are the most common conditions. Synoptically, a pressure trough to the north generally runs from Turkey down to the Persian Gulf drawing north-north-western winds steadily in from the Mediterranean for most of the year. Until around October, the summer climate is dominated by Hadley subsidence and strong inversions, which inhibit convection. During autumn, these inversions tend to weaken, and the Mediterranean and its winter cyclones start to have more influence. Precipitation is usually convective when it occurs, either embedded in the passage of fronts or induced by local circulations (Perlin and Alpert, 2001).

This study focuses on the area of the northern edge of Israel's Negev Desert close to the city of Be'ér Sheva' (see Fig. 1, inset) around $50 \mathrm{~km}$ from the coast $\left(31.24^{\circ} \mathrm{N}\right.$, $34.72^{\circ} \mathrm{E}$ ). This lies roughly on the border of two climatic zones - a semi-arid one with crops and grasslands to the north, and an arid one to the south. In this desert area various plantations exist. Among them are a jatropha and a jojoba plantation, which are the subject of this investigation and as a control case, a dry desert area was chosen. All cases are located approximately $2 \mathrm{~km}$ to the west of Be'ér Sheva'.

The "Desert" case study is situated on bare, desert soil with no vegetation, marked (1) in Fig. 1. Some small plantations exist around $800 \mathrm{~m}$ upwind but it is assumed that moisture advection to the sensors would not be significant and that non-advected quantities such as surface radiation and soil temperature would be representative of a desert surface. The "Jatropha" case study (2) is a 2 ha irrigated Jatropha curcas plantation and the "Jojoba" case study (3) is a 400 ha plantation of irrigated jojoba with a canopy height of around 3$3.5 \mathrm{~m}$. Both plantations are irrigated with secondary treated waste water from Be'ér Sheva', with low water salinity, i.e. the plantation's managers report that mean electrical conductivity (EC) of the irrigation water is $\sim 1 \mathrm{dS} \mathrm{m}^{-1}$ (see Appendix $\mathrm{B}$ for more information about salinity). The experimental jatropha plantation is irrigated only from March to December and is heavily pruned during the winter. Because of this, the canopy cover is still only around $50-60 \%$ at the beginning of June. This increased over the summer to nearly $100 \%$ during July. This is likely to bias the Jatropha observations somewhat (compared to a fully mature jatropha canopy) due to gradual changes in wind speed, albedo, evaporation and so on. Due to the small size of the jatropha plantation and the changing canopy conditions, it was decided that only the Jojoba observations would be used for validation. The Jatropha observations are however, examined and compared with the Jojoba observations (see Sect. 3.2) and yield interesting information on differences in solar and thermal radiation components between the crops.

The jojoba plantation is fully mature and watered all year round. The shrubs are widely spaced for mechanized harvesting $(4 \times 2.5 \mathrm{~m})$ producing canopy coverage of around $70 \%$ for the mature sections. These factors, consequently, are likely to produce differences in albedo, wind flow, turbulence, evaporation, skin and air temperatures and other quantities when compared with a $100 \%$ canopy closure. The soils within the plantation are mainly composed of silty to sandy loam, loess soils by local soil survey.

While the jatropha plantation is being tested with various sub-surface treatments, the jojoba plantation is fed by a sophisticated, sub-surface deficit irrigation system configured to maximize water use efficiency and yield. Water requirements are estimated by agronomists using meteorology data and standard methods. The irrigation flow rates, duration and dripper spacing are optimized to minimize losses to percolation, runoff and direct evaporation. Given that (a) there is little precipitation, (b) the irrigation is sub-surface and (c) the dosage is carefully calibrated, these losses are assumed to be negligible. Therefore, based on these assumptions, only the 


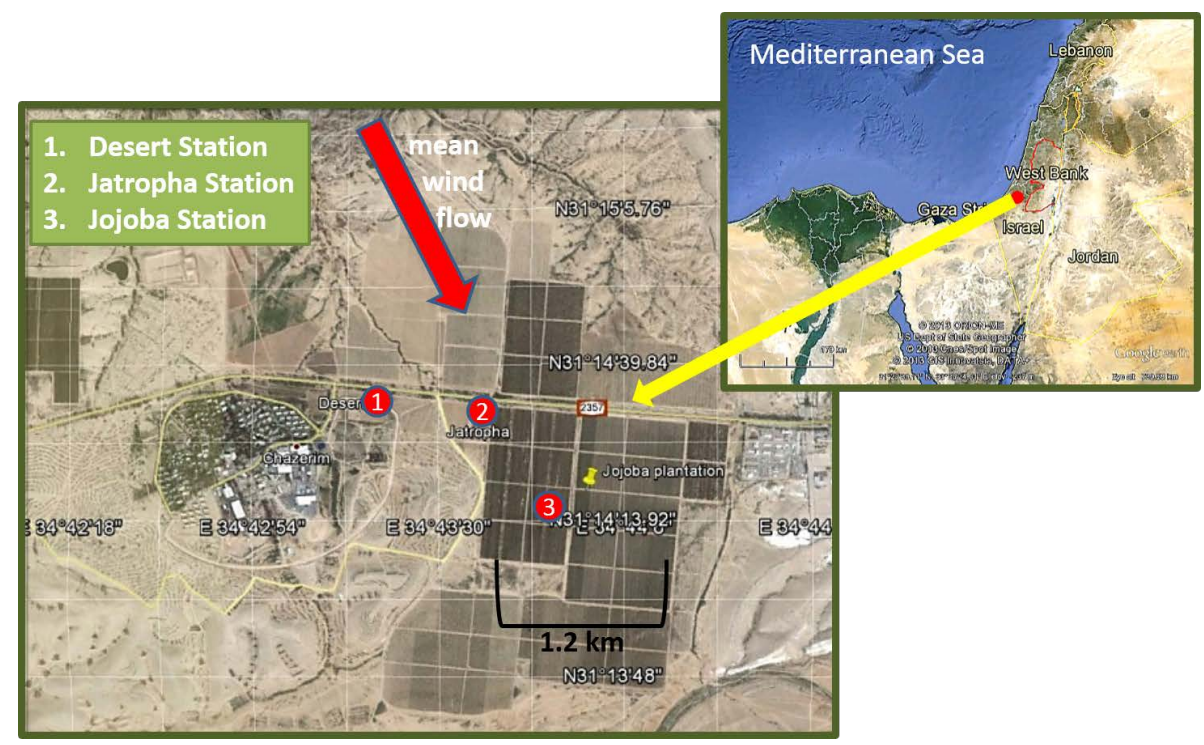

Fig. 1. The region of interest over Israel at the eastern edge of the Mediterranean Sea (inset) and the location of the three meteorological stations at Kibbutz Hatzerim in the centre of Israel, $40 \mathrm{~km}$ from the coast (the regional location is indicated by in the inset box). The location of the stations Desert (1), Jatropha (2) and Jojoba (3) are marked on the left-hand image. Mean wind flow is marked with an arrow.

Table 1. Measured quantities from Desert, Jatropha and Jojoba cases, sensor type and estimated measurement errors. Measurement errors are rated usually within a range of, or at a given temperature. Where this is applicable, the temperature range is indicated by and at sign.

\begin{tabular}{lll}
\hline Quantity & Sensor & Estimated error \\
\hline $2 \mathrm{~m}$ air temperature $(T 2)$ & Vaisala HMP155A & At $20^{\circ} \mathrm{C} \pm(0.055+0.0057 \times T)^{\circ} \mathrm{C}$ \\
$2 \mathrm{~m}$ relative humidity $(\mathrm{RH})$ & Vaisala HMP155A & At $-20+40^{\circ} \mathrm{C} \pm(1.0+0.008 \times$ reading $) \% \mathrm{RH}$ \\
Short and long wave radiation $(\mathrm{SW} / \mathrm{LW})$ & Hukseflux NR01 & $\pm 10 \%$ for $12 \mathrm{~h}$ totals \\
$6 \mathrm{~m}$ wind speed and direction $\left(U\right.$ and $\left.U_{\text {dir }}\right)$ & Gill 2-D Windsonic & $U \pm 2 \% U_{\text {dir } 2-3^{\circ}}$ \\
Barometric surface pressure $(\mathrm{BP})$ & Vaisala CS106 & $\pm 0.6 \mathrm{hPa}$ at 0 to $+40^{\circ} \mathrm{C}$ \\
Soil temperatures at 5 and $25 \mathrm{~cm}(\mathrm{ST} 5$ and ST25) & CS 108 Thermopile & $\pm 0.3^{\circ} \mathrm{C}$ at -3 to $90^{\circ} \mathrm{C}$ \\
Soil heat flux $(G$, two plates per station) & Hukseflux HFP01 & within -15 to $+5 \%$ for $12 \mathrm{~h}$ totals \\
\hline
\end{tabular}

potential and transpired evaporation terms would play a role within the NOAH evaporation equation (Appendix A). The plants are watered directly at the root ball $(35 \mathrm{~cm}$ deep) in alternate crop rows. Soil moisture $(\Theta)$ is monitored by a sensor network, and constrained to a fraction of between 0.16 and 0.30 so that the plant is neither water-stressed nor overwatered. This means that the frequency of watering can be irregular depending on environmental conditions such as radiation magnitudes, phenological stage and so on. The stem spacing of the jojoba plantation also means that soil moisture is highly heterogeneous spatially. Irrigation information comes from the jojoba plantation agronomists.

\section{Measurements}

\subsection{Site description and meteorological observations}

The variables measured and the sensor array are described in Table 1. A scan rate of $5 \mathrm{~s}$ was used for measuring and the data was averaged over $10 \mathrm{~min}$ intervals. Other useful variables were then derived from these measurement data. Albedo was calculated from the individual observed radiation components as $\mathrm{SW}_{\mathrm{UP}} / \mathrm{SW}_{\text {DOWN }}$ and net surface radiation $\left(R_{\mathrm{n}}\right)$ is calculated as $\mathrm{SW}_{\mathrm{DOWN}}-\mathrm{SW}_{\mathrm{UP}}+\mathrm{LW}_{\mathrm{DOWN}}-\mathrm{LW}_{\mathrm{UP}}$. The vapour pressure deficit $(\mathrm{hPa})$ is derived as: $e_{\mathrm{sat}}-e_{\text {actual }}$ where $e_{\mathrm{sat}}$ is the partial pressure of water vapour at saturation (hPa) and $e_{\text {actual }}$ is the actual vapour pressure.

\subsection{Analyses of observations}

A summer time series of $T 2$ and RH (Fig. 2) was examined from the three stations to assess the seasonal evolution of mean temperatures and relative humidity along with maxima and minima. The purpose of doing so was to reveal any major seasonal shifts, to assess the validity of examining seasonal diurnal curves, and to explain some of the hourly variance. Figure 2 indicates a general seasonal $T 2$ pattern, peaking in 

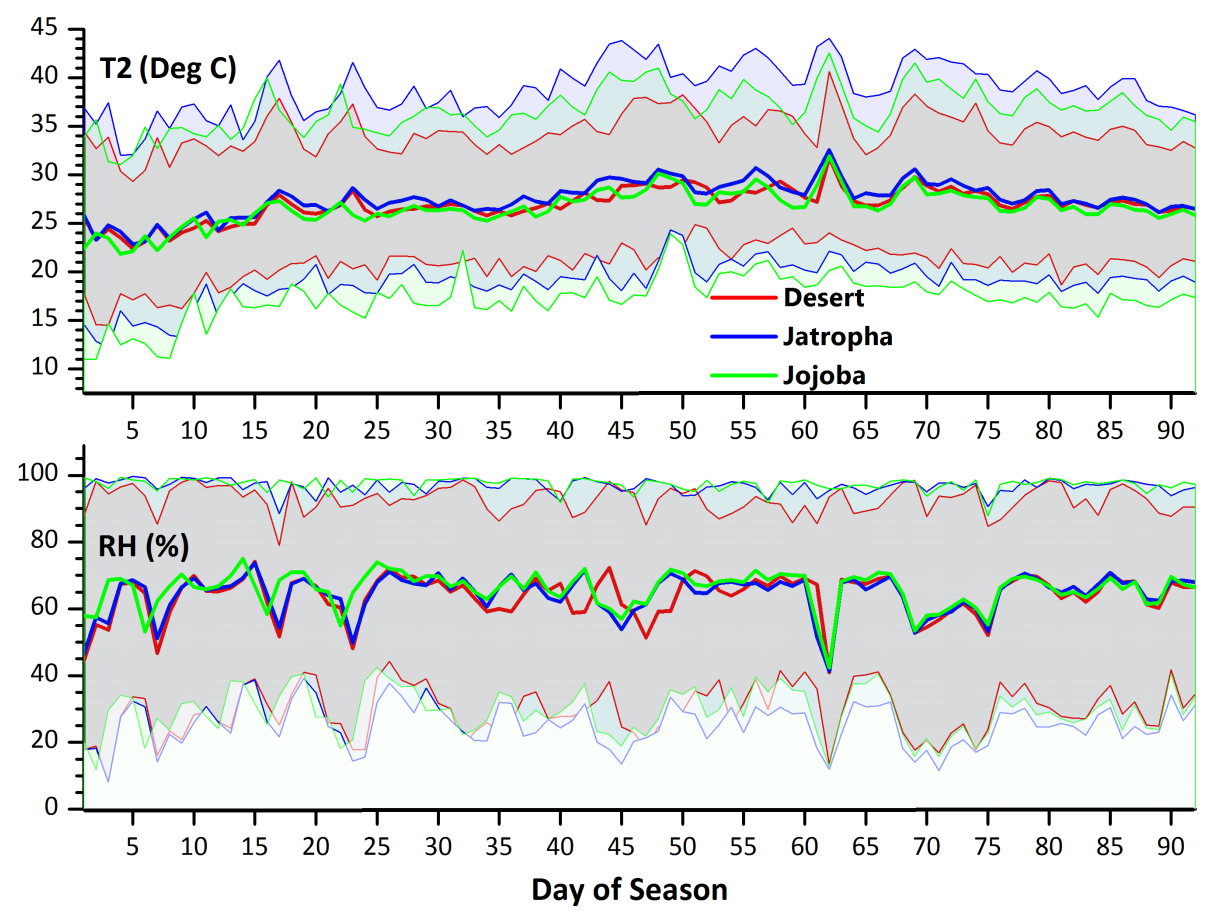

Fig. 2. Observed daily mean, maxima and minima of $2 \mathrm{~m}$ air temperatures and relative humidities for the Desert, Jatropha and Jojoba stations - summer 2012 (JJA). The thick curves at the centre of the shaded areas are the daily mean values. The upper and lower thin lines bounding the shaded areas are the daily maxima and minima.

July with daily means $2-3^{\circ} \mathrm{C}$ warmer than in June. Desert is warmer at night but cooler during the daytime than the plantations with the Jojoba $T 2$ lower in general than Jatropha. Relative humidities remain fairly constant indicating more humidity during July where higher July $T 2$ signifies higher saturation values. The Jojoba and Jatropha RH curves match very closely but Desert exhibits lower maximum RH during the night, reflecting the higher $T 2$ minimum.

Net radiation $\left(R_{\mathrm{n}}\right)$ values peak at the end of June and then decrease steadily over the season (see Fig. 3). Jojoba has a higher $R_{\mathrm{n}}$ than Jatropha especially over July, reflecting the lower albedo of Jojoba, and the Desert station has between 80 to $100 \mathrm{~W} \mathrm{~m}^{-2}$ less peak $R_{\mathrm{n}}$ than either of the plantations. Mean $U$ is quite constant over Desert and Jojoba, but over Jatropha it decreases somewhat over the season $\left(0.5 \mathrm{~m} \mathrm{~s}^{-1}\right)$ probably reflecting the Jatropha's canopy development and corresponding increase in drag. Winds speeds are in general a little higher over Jojoba than over Jatropha. There is a high variability in mean $U$ direction and the 7 day mean indicates a slight shift of around $10^{\circ}$ to the west through the season, for all stations. Surface wind speeds over Desert reach 5$6 \mathrm{~m} \mathrm{~s}^{-1}$ and are in general higher than over the plantations $\left(3-4 \mathrm{~m} \mathrm{~s}^{-1}\right)$ and also very slightly more northerly, indicating the effect of drag and a tendency towards gradient flows over the canopy. Surface air pressures $(P)$ in Fig. 3 tend to vary inversely with the seasonal temperatures, but with large variations over periods of a few days, in accordance with changing large-scale pressure systems.

Considering mean diurnal statistics (Fig. 4), T2 values over the plantations exhibit larger amplitudes than over the desert being warmer in the daytime and cooler at night. Jatropha is warmer than the Jojoba during the day $\left(+2{ }^{\circ} \mathrm{C}\right)$ and also at night $\left(+1\right.$ or $\left.2^{\circ} \mathrm{C}\right)$. Day and nighttime $\mathrm{RH}$ values are fairly similar and reflect the differences in temperature over the day. Wind speeds over Desert are higher with a pronounced daytime peak late in the afternoon, $2.5 \mathrm{~m} \mathrm{~s}^{-1}$ higher than the plantations. Daytime peak $R_{\mathrm{n}}$ values are around $350 \mathrm{~W} \mathrm{~m}^{-2}$ higher over both plantations than over Desert, but with similar losses at night time. Daytime Jojoba albedo values are noticeably lower than the Jatropha and this is reflected in the greater Jojoba $R_{\mathrm{n}}$ values.

\section{Model simulations}

This analysis is carried out via high resolution model simulations with the WRF-NOAH model. In relation to subsequent impact studies, this study focuses on the configuration and validation of the model for an arid region. Additionally, as a first examination of vegetation impacts, the energy fluxes estimated by NOAH are investigated, since these express the interaction of the atmosphere and the land surface. The model domain spans $888 \times 888 \mathrm{~km}$ and is centred over the state of Israel (see Fig. 5). 

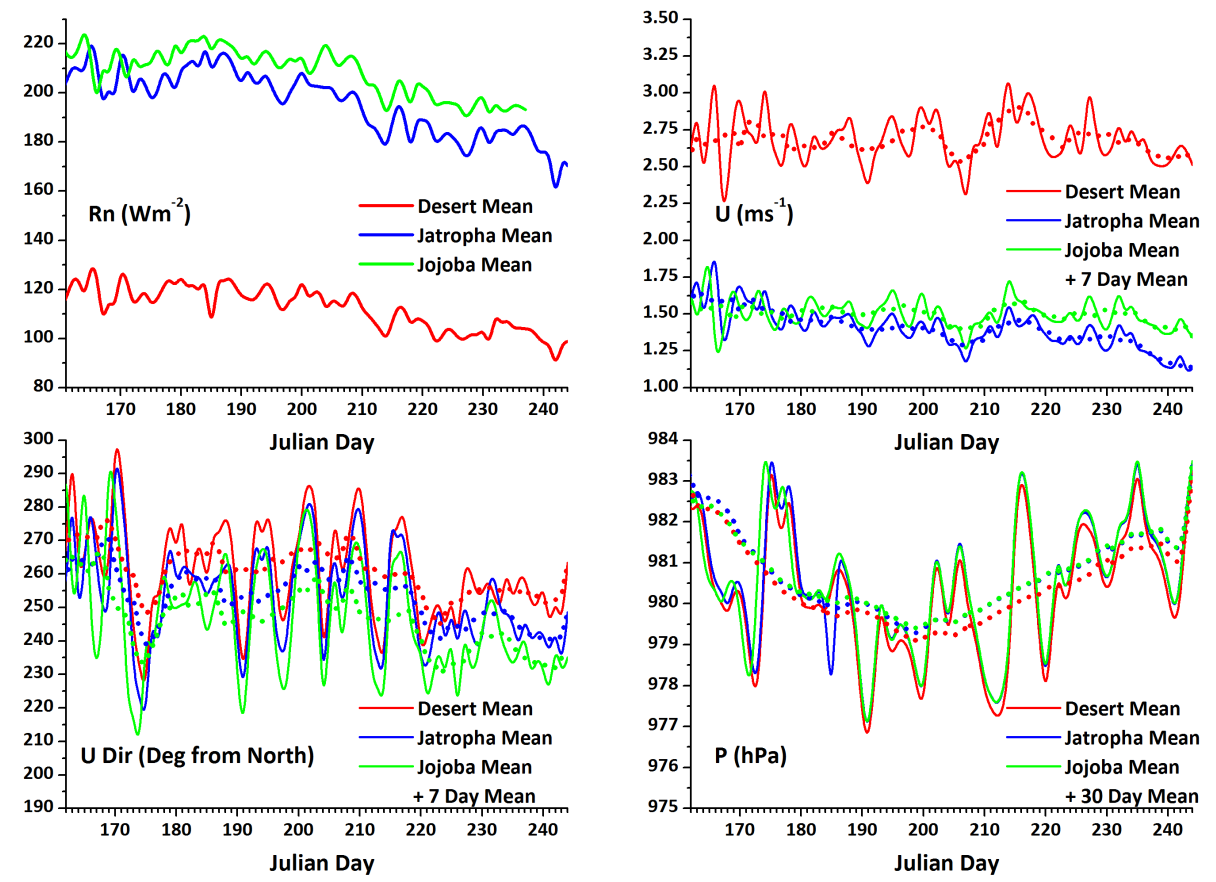

Fig. 3. Observed daily $24 \mathrm{~h}$ mean values of $R_{\mathrm{n}}, U, P, U$ and $U$ direction. 7 or 30 day means are plotted for $U, U_{\text {Dir }}$ and $P$ based on peak analysis to highlight differences between the stations and the evolution of the summer climate (2012-JJA). Due to poor quality flags some Jojoba $R_{\mathrm{n}}$ data were rejected for the last 8 days of the season.
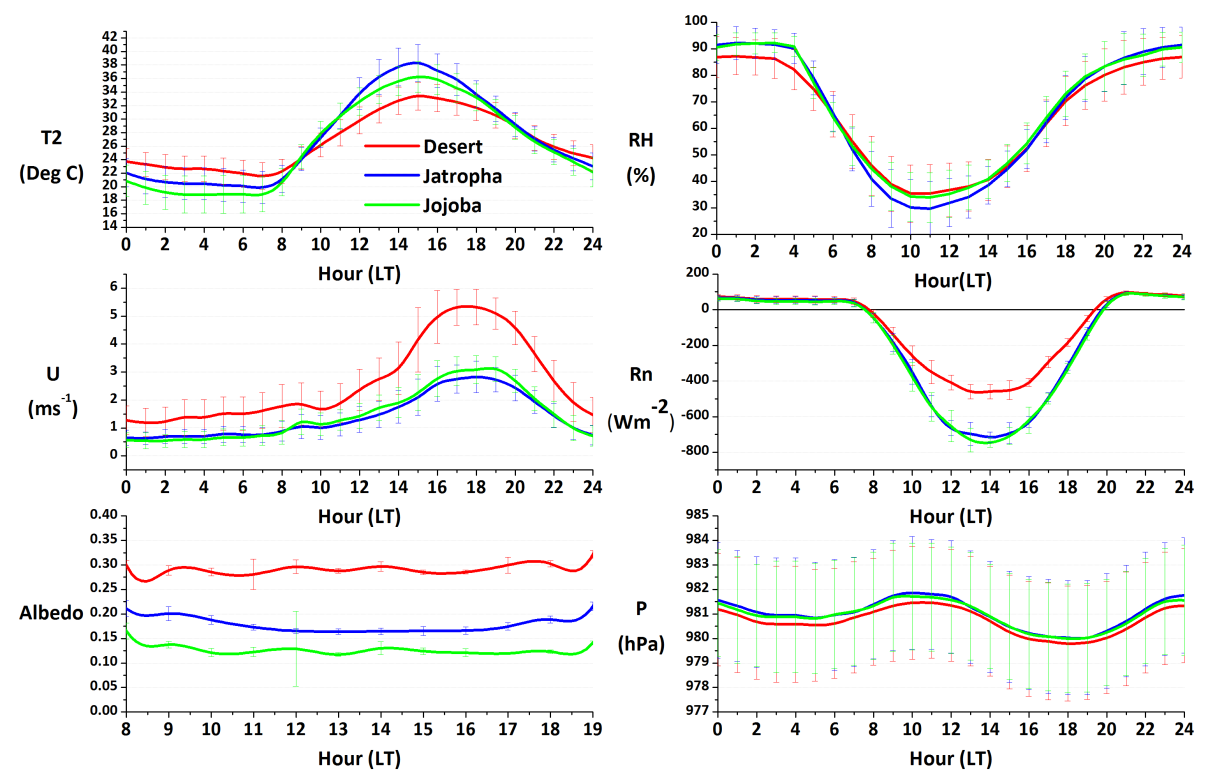

Fig. 4. Observed mean diurnal cycle of $T 2$, RH, $U(6 \mathrm{~m}), R_{\mathrm{n}}$, albedo and $P-2012$ (JJA). The error bars represent temporal standard deviation.

To judge the model performance and configuration, two cases are assessed. The first is the baseline (WRF Control). The second is a simulation of a $10 \times 10 \mathrm{~km}$ irrigated plantation (WRF Impact). WRF Control observations are compared to the Desert observations and WRF Impact observations are compared with observations from Jojoba and Jatropha. The ultimate goal, although not in this paper, will be to use the WRF-NOAH model to investigate the impact of horizontal flux gradients on ABL development and convection initiation or suppression. To ensure that these gradients are representative, the model should be able to reproduce the energy balance correctly over both surfaces. For that purpose, this 
Table 2. Physics schemes used for the study within the WRF atmospheric model.

\begin{tabular}{lll}
\hline Physics & Scheme & References \\
\hline Boundary layer & YSU (Yonsei University) & Hong et al. (2006) \\
Surface layer & MM5 Monin-Obhukov & Paulson (1970), Dyer and Hicks (1970), Webb (1970), Beljaars (1995) \\
Microphysics & Morrison 2-moment & Morrison and Gettelman (2008) \\
Shortwave radiation & RRTMG & Iacono et al. (2008) \\
Longwave radiation & RRTMG & Mlawer et al. (1997) \\
\hline
\end{tabular}

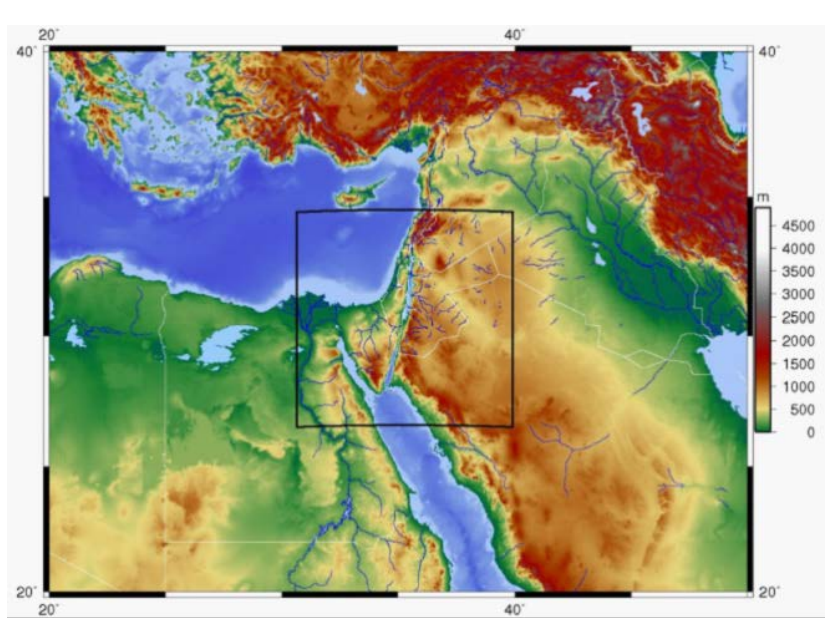

Fig. 5. Topographic map of the region of interest, at the eastern end of the Mediterranean. The model domain (approx. $888 \times 888 \mathrm{~km}$ ) is marked in the centre with a black line.

study examines the correct reproduction of the fluxes over desert and vegetated surfaces.

\subsection{Modelling configuration}

The Advanced Research WRF (ARW; WRF-ARW 3.4.1) non-hydrostatic atmospheric model, coupled with the NOAH land surface model (LSM) was configured with a $444 \times 444$ cell grid with 92 vertical levels and a $2 \mathrm{~km}$ grid horizontal increment. A single downscaled model domain was chosen with care to capture most large-scale features, such as the influx of sea air from the north-east, but to avoid orography and other strong features at the domain boundaries (see Fig. 5). The model was forced at the boundaries by ECMWF (European Centre for Medium Range Weather Forecasting) 6-hourly analysis data at $0.125^{\circ}$ grid increments and with 6hourly updated sea surface temperatures (SSTs). The model physics schemes used are shown in Table 2. Model physics schemes were chosen with consideration to the following:

- how relevant processes are dealt with and relevance to arid regions, land-surface/atmosphere feedbacks and convection;

- experience and sensitivity tests within the working group and within the WRF model community;
- which variables are explicitly calculated by, and are output from the scheme.

Additionally some schemes are designed to be paired (e.g. the SW and LW RRTMG schemes).

The YSU (ABL) and Morrison 2-moment (microphysics) schemes have been used for various publications relating to arid regions (Wulfmeyer et al., 2014; Becker et al., 2013) and temperate regions (Warrach-Sagi et al., 2013). YSU is the default WRF ABL scheme. It is non-local, explicitly handles entrainment, and is generally thought to perform well in unstable convective conditions (e.g. Shin and Hong, 2011; Hu et al., 2010), which is most relevant for examining the daytime fluxes. The MM5 surface layer scheme which computes surface exchange coefficients of heat, moisture, momentum using Monin-Obhukov stability functions, and is to be paired with the YSU (or WRF) scheme.

The Morrison 2-moment microphysics predicts total number concentration of ice species and may improve the representation of ice crystal aggregation and ice cloud radiation representation (Morrison and Gettelman, 2008). One study (Molthan and Colle, 2012) which used Morrison with WRF, cited that it gave the minimum difference between simulated and accumulated precipitation during a convective storm when compared to five other schemes. However, it is not known if this improvement in the representation of ice number concentrations would really improve simulations within our region of interest.

The land surface model was initialized using the International Geosphere Biosphere Programme (IGBP) MODIS 20category land use and soil texture with the Food and Agriculture Organization (FAO) State Soil Geographic (STATSGO) 19-category soil data set. The initial soil moisture state and lower soil boundary temperatures come from the forcing data. The model duration was 92 days over JJA, 2012 and instantaneous values were generated every hour. Full observation data sets from Desert, Jatropha and Jojoba were available for this period.

In the absence of accurate, gridded, initial soil moisture $(\Theta)$ conditions, a spin-up period is needed to allow soil moisture within NOAH to approach equilibrium within the hydrological cycle. The optimal spin-up period for any particular application is uncertain and may depend on the, regional characteristics, accuracy of initial soil conditions, temporal and spatial resolution applied as well as other factors (Lim 
Table 3. Modifications to model vegetation parameters, based on literature, sensitivity tests and local data.

\begin{tabular}{llll}
\hline Modifications & $\begin{array}{l}\text { Default } \\
\text { value }\end{array}$ & $\begin{array}{l}\text { Prescribed } \\
\text { value }\end{array}$ & Source \\
\hline Roughness $-Z_{0}(\mathrm{~m})$ & $0.5 \mathrm{~m}$ & $0.3 \mathrm{~m}$ & Literature, canopy height \\
Albedo & 0.12 & 0.12 & Observations \\
Veg. fraction $-\sigma_{\mathrm{f}}(\%)$ & $95 \%$ & $70 \%$ & Local knowledge \\
Min. stom. resistance $-R_{C_{\min }}\left(\mathrm{s} \mathrm{m}^{-1}\right)$ & 120 & 250 & 7 th International Conference on Jojoba \\
\hline
\end{tabular}

et al., 2012; Du et al., 2006). Du et al. (2006) simulate soil moisture in East Asia using the CLM model (Community Land Model) at $0.5^{\circ}$ grid spacing, and proposes that the time interval between a precipitation perturbation and reaching an equilibrium is proportional to soil depth. He also says that surface soils $(0-10 \mathrm{~cm})$ may require a few months to reach equilibrium. Lim et al. (2012) ran five year comparisons in differing climates using NOAH at around a $0.1^{\circ}$ spacing and concluded that arid soils may require considerable periods, possibly even years to reach equilibrium when compared with a monsoonal climate. Using such fine grid scales the required resources needed for such spin-up periods are simply prohibitive for many applications. In this case a one month spin up period was chosen as the longest period feasible, with the admission that for the control run, even one year might not be sufficient for a true equilibrium to be reached. However, within the simulated plantations, the sub-layers are in any case artificially moistened, and the target $\Theta$ level reached after approximately one day (see next section).

\subsection{Irrigated plantations in NOAH}

At the time of our simulations there were no official releases of WRF with irrigation schemes implemented in the accompanying NOAH or the newer NOAH-MP (multi-physics) land surface models. Schemes have been devised by others independently though and incorporated into WRF for impact studies (see Harding and Snyder, 2012; Sridhar, 2013). Sridhar for instance simulated two kinds of surface irrigation: flood and sprinkler systems. In our case, a controllable subsurface scheme was required, to reflect the sophisticated system used in Israel and so this was developed as a sub-routine and incorporated into NOAH for this study. The scheme was intended to mimic the actual jojoba plantation characteristics as closely as possible, therefore attention was given to the following factors: plantation location, size and shape; subsurface irrigation scheme/soil moisture and vegetation and soil parameters. A hypothetical plantation was introduced by modifying the land surface properties in the static land surface data used by the model (see Fig. 6). It should be emphasized that the intention is not to simulate detailed spatiotemporal phenomena over the actual $4 \mathrm{~km}^{2}$ observed plantation, where a more explicit resolution could be more appropriate. Rather we seek a good statistical representation of the diurnal fluxes over a homogeneous plantation.

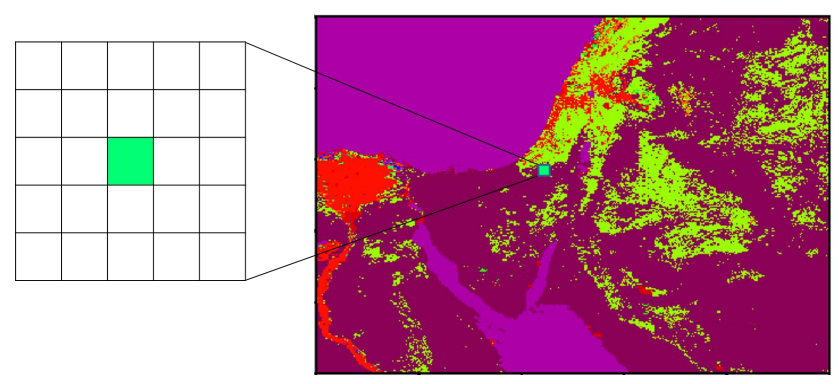

Fig. 6. Setup of the analysis of WRF output data. The image on the right is of the 20-category 30 arc second MODIS land use data set, a static data set for model initialization (all 25 cells are classed as desert/scrub in the MODIS data). A 25 cell grid box (left panel) was used, over which all variables values were averaged spatially, prior to the calculation of temporal statistics. The centre grid cell, marked in green corresponds geographically to the location of the three surface stations. The 25 cell box $(10 \times 10 \mathrm{~km})$ was also used as a template for the simulated plantation.

A plantation size of $5 \times 5$ cell grid cells was used, representing dimensions of $10 \mathrm{~km} \times 10 \mathrm{~km}$. This is in fact larger than the actual jojoba plantation, which is closer to the size of one $2 \mathrm{~km} \times 2 \mathrm{~km}$ grid cell. Pielke Sr. (2002) suggests a minimum of 4 grid cells to resolve any one feature. There is also a risk of introducing statistical anomalies due to clustering or artefacts and therefore using multiple cells allows for spatial averaging. Independent from the model simulations, the assumption could be made that surface quantities over the $2 \mathrm{~km} \times 2 \mathrm{~km}$ jojoba plantation would acquire similar characteristics to those over a larger plantation of e.g., $10 \mathrm{~km} \times 10 \mathrm{~km}$ across. This is uncertain though because, although advection effects are likely to be greatly reduced after a few hundred metres horizontally, differences in the scale of pressure perturbations and the mean wind field may well differ with the scale of the plantation. Another factor is that the wide spacing between the jojoba plants could lead to local heterogeneities and unusual turbulent characteristics above the canopy which may differ significantly with assumptions inherent in the model. Such effects are difficult to identify with point measurements. To check our assumptions on representativeness, we later compared fluxes from the $5 \times 5$ plantation with those from a $1 \times 1$ plantation (over 
one week), and the diurnal cycles and variability were not significantly different.

Grid cells for the plantation were first re-classified from Desert/Scrub to an Evergreen Broadleaf classification as a starting point for the configuration. Then, parameters such as canopy height, minimum stomatal resistance $\left(R_{C_{\min }}\right)$ and roughness were modified further based on literature on jatropha (Rajaona et al., 2012, 2013; Niu et al., 2012) and jojoba (Benzioni, 2010; Benzioni and Dunstone, 1988), sensitivity tests and site surveys (see Table 3 ).

Realistic simulation of the sophisticated irrigation system of the jojoba plantation using a soil moisture based system in NOAH is problematic, because the sub-grid heterogeneity of $\Theta$ cannot be reproduced at $2 \mathrm{~km}$ resolution. Nevertheless, if reasonable estimates of optimal $\Theta$ for irrigation can be made, and well-chosen plant soil and parameters are used, then we may expect a reasonable reproduction of the soil/plant water hydrology. We then make estimates of ET based on Penman-Monteith methods and observations, and compare them with the model results. These comparisons should indicate whether the irrigation scheme and parameterization produces ET of a realistic magnitude.

In order to calculate irrigation inputs, attention was paid to both the soil and plant properties. A method from Choudhury and DiGirolamo (1998) was used, who collated critical values of fractional root zone available water for various species from various publications. This value $F_{\mathrm{AW}}$ is the ratio of available water to maximum available water (Eq. 1):

$F_{\mathrm{AW}}=\frac{\Theta-\Theta_{\mathrm{WP}}}{\Theta_{\mathrm{FC}}-\Theta_{\mathrm{WP}}}$

where $F_{\mathrm{AW}}$ is the critical value, $\Theta_{\mathrm{WP}}$ is the soil wilting point and $\Theta_{\mathrm{FC}}$ is the field capacity. If the soil conditions such as $\Theta$ and soil texture, are such that this ratio falls below the critical value then the plant is expected to experience stress. $F_{\mathrm{AW}}$ values for various species are quoted by Choudhury, but not for jatropha or jojoba. The variability in quoted $F_{\mathrm{AW}}$ values for plants of a similar biomass were not that varied - mostly between 0.3 and 0.4 , with the only extremes being 0.25 for cotton and wheat and 0.50 for grasses. Sorghum, which like jojoba and jatropha requires a warm climate and is drought resistant, is accorded $F_{\mathrm{AW}}$ values of 0.37 and 0.35 by two separate studies, as reported by Choudhury. This represents the closest match in terms of climatic envelope as it can survive in semi-arid climates. Using the soil texture data a $\Theta$ value of around 0.39 was calculated for $F_{\mathrm{AW}}$ and rounded up to 0.4 . This yields a value of $0.18 \mathrm{~m}^{3} \mathrm{~m}^{-3}$ which was used for the irrigation target moisture level. The results should therefore be interpreted under the assumption that $0.18 \mathrm{~m}^{3} \mathrm{~m}^{-3}$ is the minimum permissible water input for the plants. This also relies on the assumption that the deficit irrigation techniques minimize the water quantities need for the plants to thrive.

For soil moisture transport NOAH uses a layer discretized version of the Richards equation (Eq. 2) with four soil layers of thicknesses: 10, 30, 60 and $100 \mathrm{~cm}$ (from the surface layer downwards). There is a free drainage scheme at the lower boundary.

$$
\begin{aligned}
& d_{z_{1}} \frac{\partial \Theta_{1}}{\partial t}=-D\left(\frac{\partial \Theta}{\partial z}\right)_{z 1}-K_{z_{1}}+P_{\mathrm{D}}-R-E_{\mathrm{dir}}-E_{t_{1}} \\
& d_{z_{2}} \frac{\partial \Theta_{2}}{\partial t}=D\left(\frac{\partial \Theta}{\partial z}\right)_{z_{1}}-D\left(\frac{\partial \Theta}{\partial z}\right)_{z_{2}}+K_{z_{1}}-K_{z_{2}}-E_{t_{2}}+I_{\Theta} \\
& d_{z_{3}} \frac{\partial \Theta_{3}}{\partial t}=D\left(\frac{\partial \Theta}{\partial z}\right)_{z_{2}}-D\left(\frac{\partial \Theta}{\partial z}\right)_{z_{3}}+K_{z_{2}}-K_{z_{3}}-E_{t_{3}}+I_{\Theta} \\
& d_{z_{4}} \frac{\partial \Theta_{4}}{\partial t}=D\left(\frac{\partial \Theta}{\partial z}\right)_{z_{3}}-D\left(\frac{\partial \Theta}{\partial z}\right)_{z_{4}}+K_{z_{3}}-K_{z_{4}}-E_{t_{4}}
\end{aligned}
$$

where $D$ is hydraulic diffusivity, $K$ is the soil hydraulic conductivity, $P_{\mathrm{D}}$ is precipitation, $R$ is surface runoff and $E_{t_{i}}$ is the layer root uptake.

The soil was irrigated by adding an extra irrigation term $\left(I_{\Theta}\right)$ to the appropriate soil layers. To assess which layers should be irrigated, a site inspection was made, and a lateral distribution radius of $30-40 \mathrm{~cm}$ was observed around the pipe. Therefore water was added to the second and third soil layers to approximate this depth and water distribution. The $\Theta$ level was replenished every 7 days to each sub-surface layer independently using the following logical statement: "IF $\Theta_{2,3}<0.18$ THEN add water. IF $\Theta_{2,3}>0.18$ THEN do not add water".

Adding water to only two of the sub-surface layers caused the model to become unstable due to the matrix method of solving the discretized equations. Therefore the water had to be added slowly $(0.0004 \mathrm{~mm} / 18 \mathrm{~s}$ timestep) and the constraining parameter in the water-balance error mechanism had to be adjusted.

Because the entire volume of each soil layer was wetted, the drainage over time is very slow, despite losses to uptake and deep percolation, and therefore after the first day of irrigation, $\Theta$ remains almost constant over the seven day intervals $(0.18 \pm 0.002)$. The reproduction of soil drainage characteristics over time still remains a problem therefore, because in reality the $\Theta$ fluctuation would be larger and more rapid from a smaller wetted volume. Therefore, the variability in canopy ET at short time scales of e.g., a few days, may not be well represented by the model because in reality the soil may dry before the sensors activate new irrigation and higher resistances are likely to occur briefly. In this model simulation therefore, ET is therefore still limited by $\Theta$, but only in terms of the target level applied and not by varying levels of moisture due to soil moisture spatial heterogeneity, as may happen in reality. Well-reproduced daily variability therefore, might not always be expected but representative diurnal ET magnitudes based on target $\Theta$ levels and the environmental conditions are assumed. 


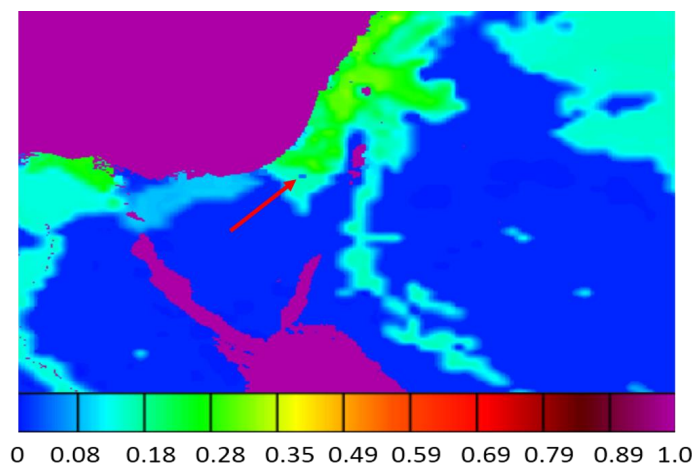

Fig. 7. ECMWF soil moisture initialization data for the second soil layer in NOAH $(10-40 \mathrm{~cm})$. The re-initialization of the soil moisture within the plantation can be seen on the image marked with a red arrow where there is a small patch which is much drier than the surroundings.

\subsection{Soils within the plantations}

The soils within the plantation are classified as clay loam by the FAO model soil data. Local soil survey data estimates that soils at the plantation are mainly composed of silty to sandy loam, loess soils. These were therefore reclassified to a sandy loam category both in Impact and Control. Parameters were then refined further using local survey data (see Table 4).

Soil moisture initialization values seemed to be unrealistic in the 2nd and 3rd soil layers (see Fig. 7) where $\Theta$ fractions of $0.2-0.28$ were prevalent, particularly upwind of the plantations and in the desert. These $\Theta$ levels approach field capacity for sandy loam soils. Values closer to wilting point are likely to be more realistic during summer after a dry 2012 spring, even at $0.5 \mathrm{~m}$. However, this could not be confirmed as quality data was not available. Nevertheless, if the sub-soil $\Theta$ data is unrepresentative, there could be implications for advection of moisture and perhaps the model spin-up time for the soils. The assumption was made that sub-soil $\Theta$ from unvegetated surfaces would not be a significant factor due to lack of a transport mechanism from sub-soils to the surface i.e. roots. Of course, there may still be an impact on the thermal diffusion and conductivity of the soil.

The 2nd and 3rd soil layers within the plantation boundary were re-initialized to wilting point $(0.047)$ to ensure that initial levels are below the levels prescribed by the irrigation scheme $\left(0.18 \mathrm{~m}^{3} \mathrm{~m}^{-3}\right)$. Otherwise it may have taken some time for the soil moisture to decrease to that level which would increase the spin up time. Re-initializing a wider area of soil was considered, but a method for deciding the extent and $\Theta$ value was not found.

\section{Validation}

To judge the model performance and configuration, two cases are assessed. The first is a baseline run with unmodified
Table 4. Modifications to model soil parameters, based on literature and local soil data.

\begin{tabular}{|c|c|c|c|}
\hline Modifications & $\begin{array}{l}\text { Default } \\
\text { value }\end{array}$ & $\begin{array}{l}\text { Prescribed } \\
\text { value }\end{array}$ & Source \\
\hline Soil type & Clay Loam & Sandy Loam & Local soil survey \\
\hline Sat Hyd. Cond $K_{\mathrm{S}}\left(\mathrm{m} \mathrm{s}^{-1}\right)$ & $2.45 \times 10^{-6}$ & $5.23 \times 10^{-6}$ & Local soil survey \\
\hline Porosity $\left(\mathrm{m}^{3} \mathrm{~m}^{-3}\right)$ & 0.43 & 0.38 & Local soil survey \\
\hline Field capacity $\left(\mathrm{m}^{3} \mathrm{~m}^{-3}\right)$ & 0.4 & 0.31 & Local soil survey \\
\hline
\end{tabular}
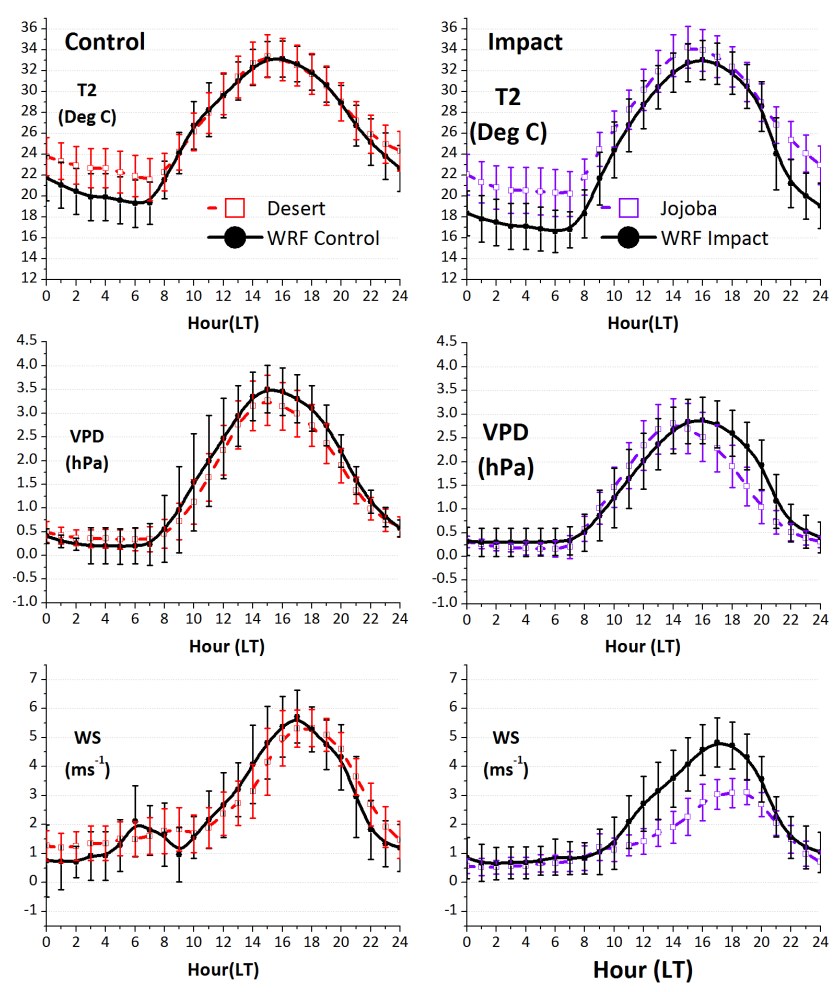

Fig. 8. Validation of WRF Control and Impact with observations for mean summer diurnal cycles of $2 \mathrm{~m}$ temperature (T2), $2 \mathrm{~m}$ vapour pressure deficit (VPD), wind speeds $(U)$. Left hand panels show Control and the right panels, Impact. WRF variables were averaged over a 25 grid cell box centred at the geographical coordinates of the Desert, Jatropha and Jojoba sites. Note: The observations have been extrapolated from the sensor height of 6 to $10 \mathrm{~m}$ as calculated by WRF.

MODIS land surface data (WRF Control). The second is a simulation of a $10 \mathrm{~km} \times 10 \mathrm{~km}$ irrigated plantation (WRF Impact). WRF Control is compared to observations from a desert surface. WRF Impact is compared with observations from jojoba and jatropha plantations.

\subsection{Comparison with observed quantities}

The validation of the Control model run against Desert observations, and Impact against Jojoba are shown in Figs. 8 and 9 as mean diurnal cycles with standard deviations as error bars. It is relevant to compare not only model against 

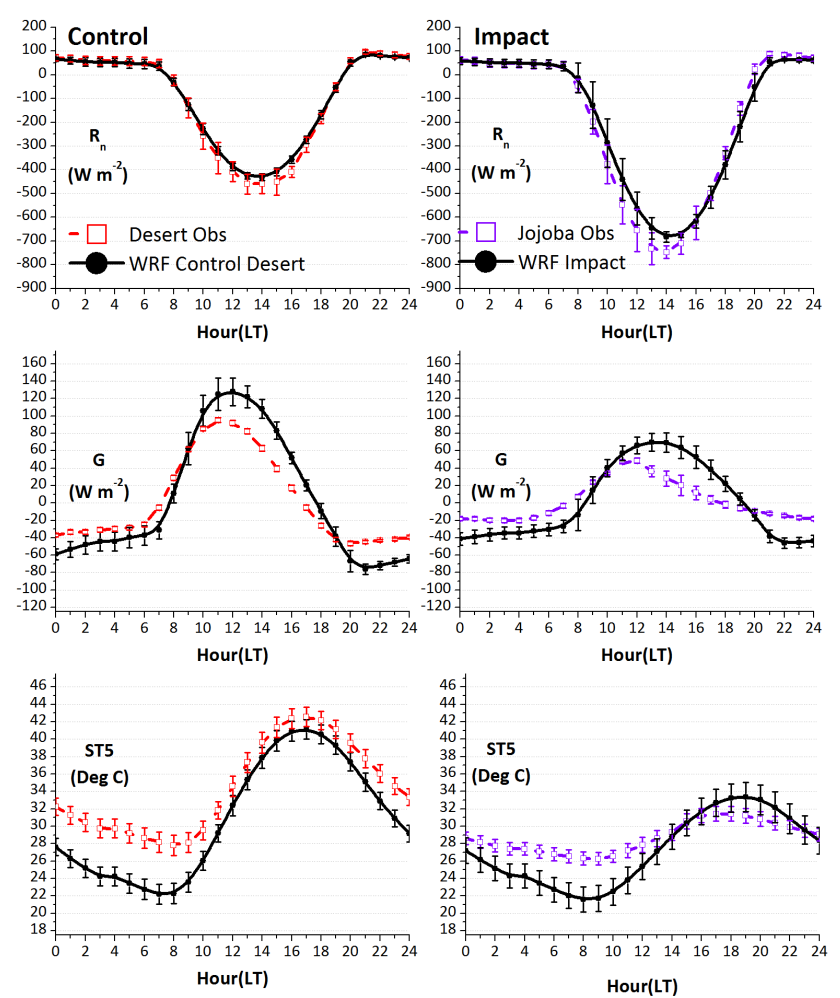

Fig. 9. Validation of WRF Control and Impact with observations for mean summer diurnal cycles of net surface radiation $\left(R_{\mathrm{n}}\right)$, ground flux $(G)$ and $5 \mathrm{~cm}$ soil temperatures (ST5).

observations, but also how the quantities compare between the cases themselves.

$T 2$ (model to observations) - during the daytime, Desert $T 2$ values are reproduced extremely well by WRF Control with almost no deviation between 08:00 and 21:00 LT The variance is well reproduced throughout the day. After 21:00 LT, the model starts to diverge and there is a significant nighttime cold bias of around $2^{\circ} \mathrm{C}$. A similar overall pattern occurs with WRF Impact which shows a strong cold bias during the night time (up to $5^{\circ} \mathrm{C}$ ). Here though, the model is also a little too cool during the day $\left(1-1.5^{\circ} \mathrm{C}\right)$. WRF Impact $T 2$ also accurately simulates the variability of Jojoba $T 2$.

$T 2$ (case comparison) - in reality, the observed daytime $T 2$ over Jojoba is warmer than over Desert $\left(1^{\circ} \mathrm{C}\right)$ but up to $2{ }^{\circ} \mathrm{C}$ cooler during the night (Fig. 8, top panels). If we compare the model's representation of this phenomenon, WRF Impact correctly predicts cooler night time $T 2$ than Control. However, this difference is larger than in reality by some margin (up to $2^{\circ} \mathrm{C}$ ). WRF Control and Impact have daytime $T 2$ which are almost equivalent, with WRF Impact $T 2$ around $0.5-1^{\circ} \mathrm{C}$ cooler than WRF Control.

VPD (model to observations) - WRF Control models the VPD quite accurately throughout the $24 \mathrm{~h}$ period including variability, with a maximum bias of $+0.2 \mathrm{hPa}$ during the afternoon when temperatures are highest. WRF Impact also models the VPD relatively well in terms of magnitudes, but exhibits a lag which could lead to a deviation in diurnal ET. The variability is also somewhat over estimated during the mornings.

VPD (case comparison) - during the middle of the day Desert VPD is $0.5 \mathrm{hPa}$ higher than Jojoba. Disregarding the bias itself, WRF models this difference accurately in both magnitude and sign. At night Desert has a slightly higher VPD than Jojoba, reflecting the higher temperatures. Jojoba VPD approaches zero in the morning indicating nearsaturated conditions.

$U$ (model to observations) - WRF Control reproduces Desert $U$ accurately, exhibiting biases of no more than $0.5 \mathrm{~m} \mathrm{~s}^{-1}$. In fact this bias appears to be one of phase rather than amplitude, with the WRF Control peak occurring later than Desert by an hour or so. There is also an unusual $U$ peak $\left(0.5-1 \mathrm{~m} \mathrm{~s}^{-1}\right)$ which occurs around 06:00-07:00 LT in WRF which is not reflected by the observations. The variability is overestimated somewhat (up to $0.5 \mathrm{~m} \mathrm{~s}^{-1}$ ). WRF Impact $U$ was compared with height corrected $U$ data from Jojoba to account for the difference in measuring height of $6 \mathrm{~m}$ and the model diagnostic height of $10 \mathrm{~m}$ (see Appendix C). The WRF Impact $U$ peak matches the observations to within $0.5 \mathrm{~m} \mathrm{~s}^{-1}$. In contrast to Control, the WRF Impact peak occurs earlier than Jojoba by around $1 \mathrm{~h}$ but is similar in that the variability is overestimated.

$U$ (case comparison) - Desert $U$ is considerably more rapid than Jojoba during the middle part of the day (5.5 and $3 \mathrm{~m} \mathrm{~s}^{-1}$, respectively) as expected due to the difference in roughness. This is only reproduced partially by WRF - predicting Desert peak $U$ to be only $1 \mathrm{~m} \mathrm{~s}^{-1}$ more rapid than Jojoba.

$R_{\mathrm{n}}$ (model to observations) - WRF Control $R_{\mathrm{n}}$ matches closely with Desert observations throughout the day and night with only a deficit of $25 \mathrm{~W} \mathrm{~m}^{-2}$ around midday. WRF Control underestimates the variability a little though during the daytime (around $15 \mathrm{~W} \mathrm{~m}^{-2}$ ). WRF Impact matches Jojoba somewhat less well with biases of up to $60-70 \mathrm{~W} \mathrm{~m}^{-2}$ (8-10\% of total magnitude), although the variability is simulated accurately.

$R_{\mathrm{n}}$ (case comparison) - during the day, observed Jojoba $R_{\mathrm{n}}$ at 01:00 LT $\left(740 \mathrm{~W} \mathrm{~m}^{-2}\right)$ reaches $300 \mathrm{~W} \mathrm{~m}^{-2}$ higher than Desert. During the night, net losses for Desert and Jojoba are quite similar - between 60 and $100 \mathrm{~W} \mathrm{~m}^{-2}$. WRF models these relative characteristics very closely.

$G$ (model to observations) - WRF Control overestimates $G$ during the day from around 10:00 LT onward. This positive bias reaches $30 \mathrm{~W} \mathrm{~m}^{-2}$ at around 00:00-01:00 LT. The variability is also somewhat overestimated. During the night, $G$ losses are overestimated - up to $25 \mathrm{~W} \mathrm{~m}^{-2}$ during the late evening. WRF Impact overestimates $G$ by up to $20 \mathrm{~W} \mathrm{~m}^{-2}$ during the day and also overestimates the upward nighttime flux also up to $20 \mathrm{~W} \mathrm{~m}^{-2}$. In both model cases the morning $G$ gradient has a slope that is too steep in comparison with the observations. Additionally in both model cases, the model 
appears to lag the observations ( 1 and $2 \mathrm{~h}$ for Control and Impact, respectively). If these anomalies were corrected, the biases would be considerably reduced over much of the day.

$G$ (case comparison) - as expected, observed peak $G$ is considerably higher in the Desert soil than in Jojoba - with a ratio of around $2: 1$. Observed nighttime $G$ losses also hold to this ratio with Desert losses larger than Jojoba. Again disregarding the absolute values, WRF reflects this daytime ratio between the surfaces.

ST5 (model to observations) - WRF Control underestimates the $5 \mathrm{~cm}$ soil temperatures, although the variability is well simulated. Both cases exhibit a significant cold nighttime bias, reflecting the bias in $T 2$. The nighttime biases approach $4{ }^{\circ} \mathrm{C}$ for both cases. During the day WRF Control converges significantly with Desert and is only $1{ }^{\circ} \mathrm{C}$ cooler around midday. WRF Impact ST5 exhibits a more damped amplitude than Jojoba and bisects Jojoba at around 3pm, then underestimating the peak ST5 by up to $2{ }^{\circ} \mathrm{C}$.

ST5 (case comparison) - Desert ST5 has a much greater amplitude $\left(15^{\circ} \mathrm{C}\right)$ than Jojoba $\left(5^{\circ} \mathrm{C}\right)$. WRF Control predicts an amplitude which is too large $\left(18.5^{\circ} \mathrm{C}\right)$ compared to Desert, likely due to the large nighttime $T 2$ bias and WRF Impact also overestimates the amplitude by around $4{ }^{\circ} \mathrm{C}$. ST5 drops to around $28^{\circ} \mathrm{C}$ at night time whereas Joj LT for Desert and around 18:00 LT for Jojoba. These peaks are modelled very well by WRF in both cases.

\subsection{Comparison with evapotranspiration estimates}

Since measurements of vertical fluxes were not available, ET was calculated independently from WRF-NOAH by applying two formulas based on Penman-Monteith equations (see below) and the observed Jojoba meteorological data. Penman-Monteith methods were thought to be appropriate here because they are often used in conditions where water is not greatly limited such as with irrigated crops. Estimations in conditions where water stress is present are more problematic and other methods may be more suitable, e.g. parameterized ET sub-models based in hydrologic models (Sumner and Jacobs, 2005). Additional estimates were examined from Becker et al. (2013) and also from a United States Agency for International Development (USAID) report (Irrigation and Crop Management Plan, 2006) - both of which discuss ET estimates for a jatropha plantation (Luxor, Egypt) in a similar summer climate (though winter is warmer and drier). Jatropha ET was not estimated because of the small plantation size and the likelihood of biases from advection.

Two methods were used: (a) the combination PenmanMonteith equation (Penman $R_{\mathrm{a}} / R_{\mathrm{S}}$ ) and (b) a modified Penman-Monteith ASCE method (Penman FAO 56) (see Appendix B for descriptions). The first method, Penman $R_{\mathrm{a}} / R_{\mathrm{S}}$ is based on the so called combination PenmanMonteith equation from Monteith (1965) which includes explicit surface and aerodynamic resistances. The second method, FAO-56 Penman-Monteith (Allen et al., 1998) was
Table 5. Mean diurnal summer evaporation over Jojoba based on calculations from Penman $R_{\mathrm{a}} / R_{\mathrm{S}}$ and Penman FAO 56. The values highlighted in bold are the daily $\mathrm{ET}_{\mathrm{C}}$ or crop and canopy fraction adjusted estimates. As mean summer diurnal values were used to calculate ET the monthly figures shown are the same. In reality there may be a little variability over the summer with changing temperatures and so on.

\begin{tabular}{llc}
\hline Jojoba & Variable & $\begin{array}{c}\text { Mean summer } \\
\text { value }\left(\mathrm{mm} \mathrm{d}^{-1}\right)\end{array}$ \\
\hline Penman $R_{\mathrm{a}} / R_{\mathrm{S}}$ & $\mathrm{ET}$ for $100 \%$ canopy & 6.51 \\
& $\mathrm{ET}_{\mathrm{c}}$ for $70 \%$ canopy & 4.56 \\
Penman FAO 56 & $\mathrm{ET}_{0}$ & 8.83 \\
& $\mathrm{ET}_{\mathrm{c}}\left(K_{\mathrm{c}} \cdot \sigma_{\mathrm{f}}\right)$ & 4.33 \\
\hline
\end{tabular}

developed by the Food and Agriculture Organization (FAO) - a standard analytic/empirical method, useful when stomatal resistance data are not available. It describes a potential or reference ET $\left(\mathrm{ET}_{0}\right)$ of a well-watered vegetated grass surface with canopy height of $0.12 \mathrm{~m}$, a constant Rs of $70 \mathrm{~s} \mathrm{~m}^{-1}$ and an albedo of 0.23 . This $\mathrm{ET}_{0}$ value is then modified with a crop coefficient $K_{\mathrm{c}}$ associated with particular plant types (see Appendix B for a detailed description of both methods and for calculations).

Both methods generally assume a neutrally stable surface layer which, given the dry convective afternoon conditions in hot, arid climates, when thermal turbulence dominates, is often not the case. Methods have been devised to include stability functions. The MM5 surface layer scheme (see Table 1) selected for the model simulations does employ a stability correction factor $(S)$ which is combined with wind speed to calculate evaporation (see Appendix A for a description). However, it is not completely clear whether the inclusion of stability correction affects ET calculations substantially or not. Mahrt and Ek (1984) discuss the significance of stability correction in a study based on the Wangara experiment. Otles and Gutowski (2005) also discuss this issue in relation to a modelling study carried out within a semi-arid climate. They tested methods with and without stability correction, and obtained fairly similar results which corresponded closely with lysimeter and flux observations. Bearing this in mind, and because the absence of profile data makes the stability regime hard to identify, no stability correction was used in this case for estimations.

The mean daytime Jojoba evaporation estimates (averaged for all summer months) from both Penman-Monteith methods are shown in Table 5 . Both methods yield very similar mean daytime $\mathrm{ET}_{\mathrm{C}}$ values (Penman $R_{\mathrm{a}} / R_{\mathrm{S}} 4.56 \mathrm{~mm} \mathrm{~d}^{-1}$ and Penman 56 FAO $4.33 \mathrm{~mm} \mathrm{~d}^{-1}$ ). The quality of these estimations were assessed through comparison with annual data gathered for the Luxor jatropha plantation, from the USAID report (also based on the FAO 56 approach). In Luxor, mean jatropha $\mathrm{ET}_{\mathrm{C}}$ values of $4.86 \mathrm{~mm} \mathrm{~d}^{-1}$ are quoted for the summertime (see Fig. 10), which is a very close match. 


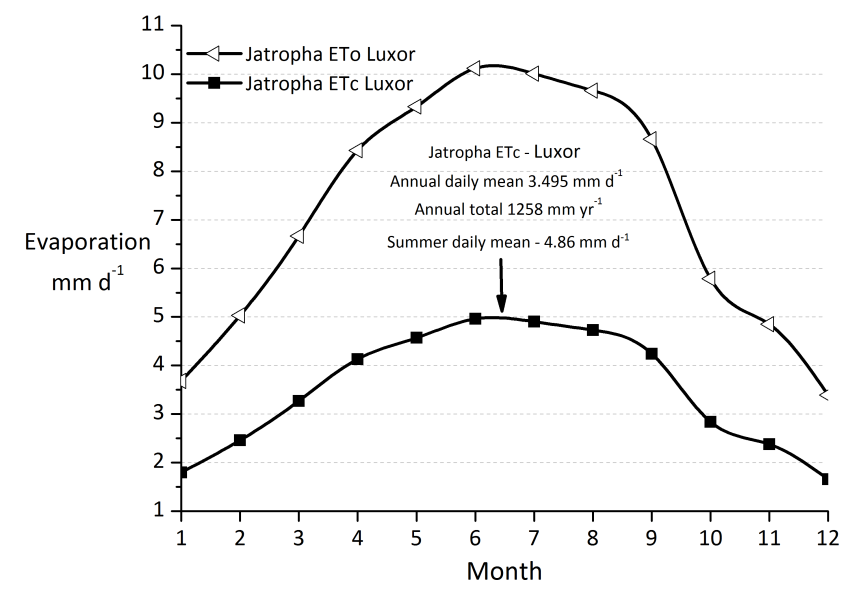

Fig. 10. $\mathrm{ET}_{0}$ and $\mathrm{ET}_{\mathrm{C}}$ values obtained for a jatropha plantation in Luxor as reported in the USAID report Irrigation and Crop Management Plan. The $\mathrm{ET}_{\mathrm{C}}$ is calculated using the Penman-Monteith FAO 56 method and a crop coefficient $K_{\mathrm{C}}$ of 0.7 for jatropha. The annual total is calculated as $1258.61 \mathrm{~mm} \mathrm{yr}^{-1}$.

The annual total $\mathrm{ET}_{\mathrm{C}}$ in Luxor is estimated to be around $1250 \mathrm{~mm}$. In Israel on the other hand, agronomists quote an annual input of $700 \mathrm{~mm}$ for jojoba (650 mm for jatropha). The average $200 \mathrm{~mm}$ of winter rain in Be'ér Sheva' can be added to that. If the above annual irrigation inputs are accurate, there still remains around a $300 \mathrm{~mm}$ difference between the Israel and Egypt totals. This difference may be attributed to (a) cruder, surface irrigation in Luxor, where greater losses to direct evaporation and runoff could be assumed, and also (b) the cooler winter climate in Israel. Therefore, less water is needed in Israel during the winter and $900 \mathrm{~mm} \mathrm{yr}^{-1}$ may therefore be a plausible water requirement. Additionally, three harvests are obtained every growing season in Luxor which necessitates more irrigation than if only two per year were taken. However, if we concentrate only on the summer months, where observations for Israel are available, then both Penman estimates (Table 5) match the Luxor ET rates (Fig. 10) to within $0.5 \mathrm{~mm} \mathrm{~d}^{-1}$.

ET from the Penman-Monteith ET estimates and from the WRF-NOAH model, are compared in Fig. 11 (left panel), and are expressed in both $\mathrm{W} \mathrm{m}^{-2}$ and $\mathrm{mm} \mathrm{d}^{-1}$. Given that we assume no losses to drainage or direct evaporation, the transpiration also represents an approximation of the plant water requirement. Therefore the JJA total requirement based on the WRF value of $4.42 \mathrm{~mm} \mathrm{~d}^{-1}$ would yield $406 \mathrm{~mm}$ over the 92 days of JJA (419 mm for Penman $R_{\mathrm{a}} / R_{\mathrm{S}}$ and $398 \mathrm{~mm}$ for Penman FAO 56).

The remainder of the energy balance for these two methods was then estimated from the $G$ and $R_{\mathrm{n}}$ observations. The WRF HFX fluxes were plotted against the plantation HFX values implied by the ET estimations, calculated as the residual of the energy balance (Eq. 3):

$\mathrm{HFX}=R_{\mathrm{n}}(\mathrm{Obs})-G(\mathrm{Obs})-\mathrm{LH}($ Estimate $)$.
$R_{\mathrm{n}}$ measurements should be fairly representative, but a good representation of $G$ is difficult to obtain without many measurement points due to: soil heterogeneity, sharp temperature gradients and diurnal changes in shading caused by the partially open Jojoba canopy. Additionally, the heat storage needs to be accounted for, requiring good estimations of wet/dry soil thermal conductivities and $\Theta$. In spite of these factors, during the middle part of the day, $G$ magnitudes play a minor role in the energy balance (for Jojoba, $5 \%$ of $R_{\mathrm{n}}$ ). Therefore, day time biases in $G$ should not overly affect estimates of the other energy fluxes, based on $R_{\mathrm{n}}-G$. During the night however, biases in $G$ could play a larger role where $R_{\mathrm{n}}$ and $G$ flux magnitudes approach each other.

The resulting Penman ET curves are quite similar in magnitude with a $1 \mathrm{~mm} \mathrm{~d}^{-1}$ or $28 \mathrm{~W} \mathrm{~m}^{-2}$ difference during the middle of the day. The Penman FAO 56 curve shows a slight lag of perhaps $1 \mathrm{~h}$, when compared with Penman $R_{\mathrm{a}} / R_{\mathrm{s}}$, and has a less peaked shape. At night, Penman FAO 56 exhibits only a very small downward flux (perhaps $5 \mathrm{~W} \mathrm{~m}^{-2}$ ), whereas Penman $R_{\mathrm{a}} / R_{\mathrm{S}}$ shows a higher downward flux of 10 - $20 \mathrm{Wm}^{-2}$. WRF Impact ET matches well in magnitude with the Penman estimates, and during the day the WRF curve falls somewhere between the two Penman curves with a maximum latent heat value of $160-170 \mathrm{~W} \mathrm{~m}^{-2}$. After sunrise, WRF Impact follows closely with the Penman $R_{\mathrm{a}} / R_{\mathrm{S}}$ ET curve until midday when the model diverges a little. Around 14:00 LT, the Penman $R_{\mathrm{a}} / R_{\mathrm{S}}$ curve drops sharply and bisects the WRF curve which predicts high ET for a longer period before dropping more smoothly downward between 14:00 and 16:00 LT. The peak time (of highest ET) in the model lies in between those from the Penman estimates, with all three curves being spaced around 30 min apart. During the latter part of the afternoon and evening, WRF matches more closely with Penman FAO 56. Both estimates vary more than WRF-NOAH especially during the morning up until midday. There could be many reasons for this. Biophysical factors not accounted for by WRF-NOAH are spatiotemporal heterogeneity in soil moisture and stomatal resistances. The influence of these factors are unquantifiable though without detailed hydrological measurements. In terms of atmospheric demand, for which we do have sufficient data, we know that $R_{\mathrm{n}}$ varies by $80 \mathrm{~W} \mathrm{~m}^{-2}$ during this time of day (Fig. 4 ) and decreases in mean daily values over the season by around $20 \mathrm{~W} \mathrm{~m}^{-2}$ (Fig. 3). From Fig. 9, $G$ varies very little at this time $\left(<10 \mathrm{~W} \mathrm{~m}^{-2}\right)$ so is not likely to influence ET significantly. $T 2$ in Jojoba also varies by $2{ }^{\circ} \mathrm{C}$ during these hours (Fig. 4) which is explained mostly by the seasonal peak in July (Fig. 3). $U$ varies only by around $0.5 \mathrm{~m} \mathrm{~s}^{-1}$ diurnally and with little drift over the season, therefore aerodynamics do not seem to play a large role. VPD varies diurnally by around $0.4 \mathrm{hPa}$ and from Fig. 3 we can surmise that there is a peak of humidity during July because it remains constant whilst $T 2$ peaks at this time. Visually it appears that $R_{\mathrm{n}}$ is the most variable during the morning hours which corresponds most closely with ET variability. Given the size of the 

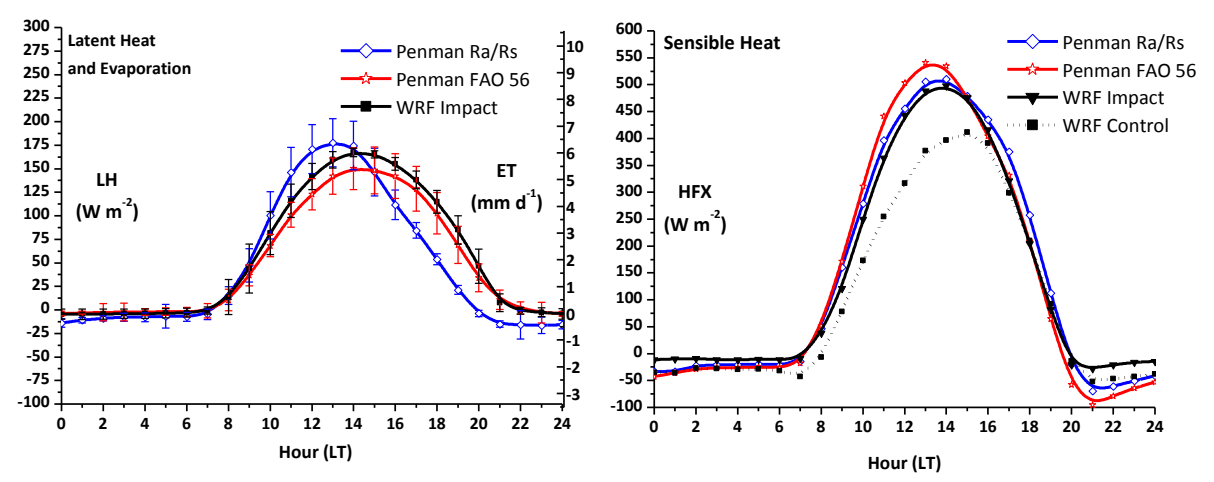

Fig. 11. Mean summer diurnal cycles of LH and HFX from WRF Impact (solid lines). Also indicated are the estimates from PenmanMonteith with $R_{\mathrm{a}} / R_{\mathrm{S}}$ and FAO-56 Penman-Monteith (dashed lines). The left hand plot shows ET expressed in W m ${ }^{-2}$ (left $y$ axis) and $\mathrm{mm} \mathrm{d}^{-1}$ (right axis) along with standard deviation. The right hand plot shows the HFX fluxes from WRF Impact and also the implied HFX based on the Penman estimates [calculated as the residual of the energy balance $R_{\mathrm{n}}(\mathrm{Obs})-G(\mathrm{Obs})-\mathrm{LH}$ (Estimation)]. HFX from WRF Control is also plotted to assess the diurnal differences between HFX from desert and from irrigated plantations.
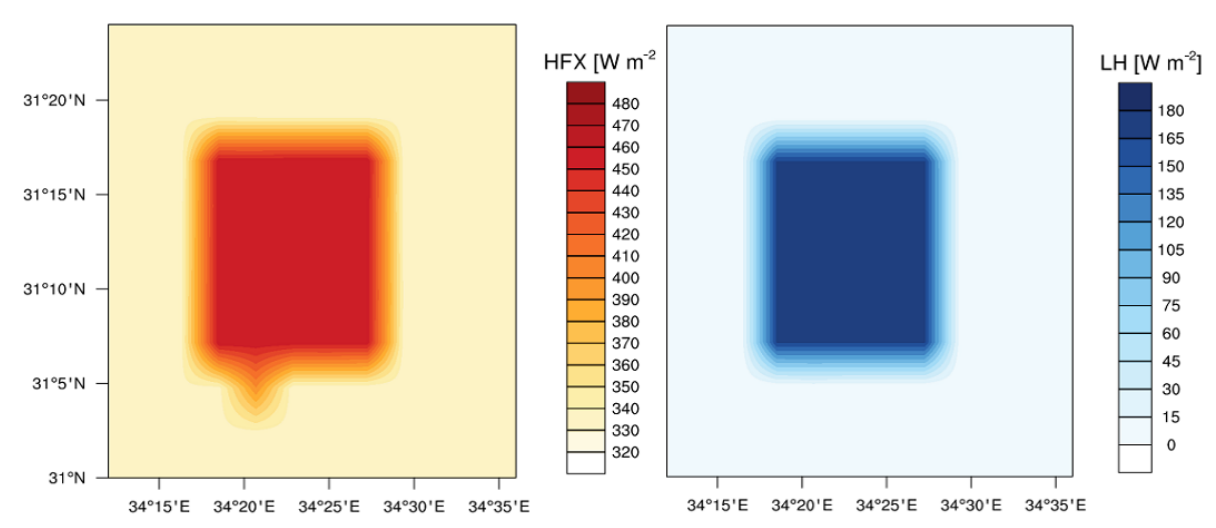

Fig. 12. Mean daily maximum of sensible and latent heat flux (JJA) in WRF Impact to show the spatial gradient between the plantation and the surrounding desert. Values of HFX over plantation and desert are around 460 and $330 \mathrm{~W} \mathrm{~m}^{-2}$ respectively (a $130 \mathrm{~W} \mathrm{~m}{ }^{-2}$ gradient). Values of LH over plantation and desert are around 165 and $0 \mathrm{~W} \mathrm{~m}^{-2}$, respectively $\left(165 \mathrm{~W} \mathrm{~m}^{-2}\right.$ gradient).

$80 \mathrm{~W} \mathrm{~m}^{-2}$ fluctuation it is likely then that $\mathrm{ET}_{0}$ variability is driven predominantly by that of $R_{\mathrm{n}}$.

For the estimated HFX (Fig. 11, right panel), WRF Control HFX is also plotted alongside WRF Impact and the two Penman estimates. WRF Impact approaches most closely to Penman $R_{\mathrm{a}} / R_{\mathrm{S}}$ in magnitude and shape. It is noticeable that HFX from both Penman estimates have higher peak magnitudes than WRF Impact, which seems contradictory to what the LH plot implies, where WRF LH falls in between the two estimates. This apparent anomaly can be explained by (a) the slightly lower WRF Impact $R_{\mathrm{n}}$ during the day and (b) the differences of alignment in peaks for observed and modelled $R_{\mathrm{n}}$ and $G$ (Fig. 9). At night time, both Penman estimates exhibit large downward HFX $\left(-50\right.$ to $\left.-100 \mathrm{~W} \mathrm{~m}^{-2}\right)$ in the late evening which is not reflected by WRF Impact.

To examine the spatial gradient between simulated plantation and the surrounding desert directly, the mean daily maximum HFX and LH flux (JJA) were plotted from WRF Impact (Fig. 12). These statistics show a plantation surplus of roughly $130 \mathrm{~W} \mathrm{~m}^{-2}$ for HFX and $165 \mathrm{~W} \mathrm{~m}^{-2}$ for $\mathrm{LH}$. There is an anomalous sensible heat flux high, extending to the south of the plantation, on a scale of around 1 grid cell. However it is not yet clear why this is so as there are no anomalies in soil or land use type at this location.

\section{Discussion}

The aim of the study was to simulate a sub-surface irrigated $100 \mathrm{~km}^{2}$ plantation in WRF-NOAH and compare diurnal statistics of $T 2, Q 2, U, R_{\mathrm{n}}, G$, ST5 and LH with desert and vegetation observations. Based on the results we can assess the model's ability to simulate desert and vegetation surfaces and examine the flux gradients over vegetation and desert. 


\subsection{Validation results}

WRF Impact diagnoses cooler morning and midday temperatures over Jojoba in contrast to WRF Control and Desert (Fig. 8) but the reasons for this are not clear. T2 measurement error is likely to be negligible (see Table 1). Perhaps the Impact nighttime cold bias is extended into the convective ABL. Another possible cause is the lag in $R_{\mathrm{n}}$, in WRF Impact during this period. Other possibilities are advection effects due to the disparity in simulated and real plantation sizes. This needs to be tested with varying plantation sizes.

The nighttime $T 2$ cold bias is large and this is reflected in the $5 \mathrm{~cm}$ soil and skin temperatures and a correspondingly low upwelling long wave flux. This could be due to poor model simulation of the stable boundary layer and $\mathrm{ABL}$ transitions.

VPD is simulated quite well (deviation $<1 \mathrm{hPa}$ ) indicating a reasonable simulation of evaporative demand (see Appendix A for NOAH evaporation mechanism). How this relates in reality to diurnal surface resistances and $\mathrm{ET}_{\mathrm{C}}$ is not so clear. Under constant light and VPD, the stomatal aperture of jojoba is controlled by the xylem water potential $(\psi)$ of the plant. Furthermore, responses to changes in $\psi$ are heavily dependent on soil and air temperatures and therefore highly non-linear (Benzioni and Dunstone, 1988).

$U$ influences the energy balance partitioning greatly, through turbulent exchanges. $U$ is well simulated over the desert and plantation. Variability is overestimated though by WRF Impact and underestimated by WRF Control. A possible source of bias is locally induced complexities in the turbulent wind field due to the open canopy. Finnegan et al. (2009) say that pressure gradients between the front and back of leaves and stems lead to unique turbulent characteristics, and suggest that Monin-Obhukov assumptions are not necessarily valid over canopies.

$R_{\mathrm{n}}$ is well modelled in Control and Impact over the day (Fig. 9). There is a slight underestimation for both cases around peak time (14:00 LT) of $30-50 \mathrm{~W} \mathrm{~m}^{-2}$. This can be explained by a simulated atmosphere which is too dry, with a reduced downwelling long wave (LW) radiation. This was investigated and a deficit does exist which accounts for nearly all of the $R_{\mathrm{n}}$ bias. This represents only a small fraction of the $R_{\mathrm{n}}$ magnitude though so it should not compromise energy balance estimates much.

$G$ is overestimated by around $30 \%$ in WRF Control, but not by WRF Impact. In both cases the morning upward slope is too sharp in the model, especially in Control. This could indicate (a) a too large temperature gradient between skin and soil, (b) misparameterized thermal conductivity, dependent on $\Theta$ (Chen and Dudhia, 2001), or (c) misclassified soil texture/characteristics. Measurement error in the desert is also a possible factor. However, the very high correlation between the two desert flux plates (0.99), more or less rules out any relative error. The contribution of $G$ to the energy balance is $5-6 \%$ in the plantation, but $20 \%$ in the desert and when there is little ET, this $G$ bias inevitably affects HFX exclusively. If the measurements are accurate, then WRF Control is underestimating HFX by around $30 \mathrm{~W} \mathrm{~m}^{-2}$ at peak time. This needs to be accounted for when comparing fluxes.

ST5 comparisons reflects the nighttime cold bias. However, the bias is strongest in Control. This can be partially explained by the greater upward $G$ in Control $\left(20 \mathrm{~W} \mathrm{~m}^{-2}\right)$ than in the plantation $\left(10-12 \mathrm{~W} \mathrm{~m}^{-2}\right)$. During the daytime the model converges again with the observations. This can be explained by the steeper model slope which allows the model to reduce the deficit somewhat.

\subsection{Diurnal energy fluxes}

In terms of ET, the model matches closely with the observations, and lies within $20 \mathrm{~W} \mathrm{~m}^{-2}$ of both curves at peak time (Fig. 11, left panel). Both the shape and the magnitude of WRF Impact lies in the middle of Penman $R_{\mathrm{a}} / R_{\mathrm{S}}$ and FAO 56. This lends confidence to the simulated peak LH of $160 \mathrm{Wm}^{-2}$. Extrapolating these fluxes to HFX, a surplus of around $120-130 \mathrm{~W} \mathrm{~m}^{-2}$ (Fig. 11, right panel) is likely between the Jojoba and Desert surfaces $\left(90-100 \mathrm{~W} \mathrm{~m}^{-2}\right.$ if we adjust for the $30 \mathrm{~W} \mathrm{~m}^{-2} G$ bias in WRF Control).

Further calibration and sensitivity tests could improve NOAH for local conditions. One area that needs some improvement is the simulation of soil thermal transport, especially on bare soils. Vertical flux, profile and soil/plant measurements are also planned for Jojoba, for validation and for further calibration of the Penman methods. In summary, the simulation of irrigated plantations and corresponding land surface exchanges has been largely successful with only limited deviations in important variables. In particular, ET seems to be well simulated, when compared to Penman-Monteith estimates and the Luxor data. Therefore, conducting further impact studies, where flux gradients need to be correctly simulated, seems a reasonable prospect with this model.

In terms of the flux gradients, a prediction can be made that HFX over plantations will be higher than over desert surfaces, mainly due to the $R_{\mathrm{n}}$ surplus and a low ET from Jojoba. These predictions differ with conclusions from some regional irrigation studies (e.g. Qian et al., 2013 and Kueppers et al., 2007) which diagnose cooler (daily mean) $T 2$ and high LH over irrigated plantations. This has significant implications for the impacts on local and regional climate if larger scale biomass plantations are planned.

Acknowledgements. Die Stiftung Energieforschung, BadenWüurttemberg is gratefully acknowledged for their generous financial backing of this research.

The authors would also like to thank their colleagues H. S. Bauer, J. Milovac, T. Schwitalla, H. D. Wizemann, A. Behrendt and Alex Geissler for continuing support and discussion. A special thank you to Dan Yakir at the Department of Environmental Sciences and Energy Research, Weizmann Institute of Science, Rehovot, Israel for his valuable scientific contributions and support. 
With thanks to the personnel at Kibbutz Hatzerim and Netafim, Israel for their continuing technical support with our measurement campaign - especially Ami Charitan, Opher Silberberg, Ronen Rothschild, Oscar Lutenberg and Eli Matan.

A part of this work was supported by a grant from the Ministry of Science, Research and Arts of Baden-Württemberg (AZ Zu 33721.3-2) and the Helmholtz Centre for Environmental Research UFZ, Leipzig (WESS project) and a part was supported by the Project PAK 346/RU 1695 funded by DFG.

Many thanks for the support from the High Performance Computing Center Stuttgart (HLRS) of the University of Stuttgart, Germany, where the simulations and analysis were performed on the CRAY XE6 system.

Edited by: F. Tian

\section{References}

Abou Kheira, A. and Atta, N.: Response of Jatropha curcas L. to water deficits: Yield, water use efficiency and oilseed characteristics, Biomass Bioenerg., 33, 1343-1350, 2009.

Allen, R., Pereira, L., Raes, D., and Allen, M.: Crop evapotranspiration: Guidelines for computing crop water requirements, FAO Irrigation and Drainage Paper No. 56, retrieved from: http://scholar.google.co.uk/scholar?hl=en\&as_sdt= $0,5 \&$ cluster $=8045698339079564915 \# 0$, Food and Agricultural Organization, Rome, 1998.

Alpert, P. and Mandel, M.: Wind Variability - An Indicator for a Mesoclimatic Change in Israel, J. Clim. Appl. Meteorol., 25, 1568-1576, 1986.

Ayers, R. S. and Westcot, D. W.: Water Quality For Agriculture, retrieved from: http://www.cabdirect.org/abstracts/19856755033. html;jsessionid=08B1B6FB48B32C38E2994EEEC7EFB14E? freeview=true (last access: 20 March 2013), 1985.

Bauer, H.-S., Weusthoff, T., Dorninger, M., Wulfmeyer, V., Schwitalla, T., Gorgas, T., Arpagaus, M., and Warrach-Sagi, K.: Predictive skill of a subset of models participating in D-PHASE in the COPS region, Q. J. Roy. Meteorol. Soc., 137, 287-305, doi:10.1002/qj.715, 2011.

Becker, K., Wulfmeyer, V., Berger, T., Gebel, J., and Münch, W.: Carbon farming in hot, dry coastal areas: an option for climate change mitigation, Earth Syst. Dynam., 4, 237-251, doi:10.5194/esd-4-237-2013, 2013.

Beljaars, A. C. M.: The parametrization of surface fluxes in largescale models under free convection, Q. J. Roy. Meteorol. Soc., 121, 255-270, doi:10.1002/qj.49712152203, 1995.

Ben-Gai, T., Bitan, A., Manes, A., and Alpert, P., 1993. Long-term change in October rainfall patterns in southern Israel, Theor. Appl. Climatol., 46, 209-217, 1993.

Ben-Gai, T., Bitan, A., Manes, A., and Alpert, P.: Long-term changes in annual rainfall patterns in southern Israel, Theor. Appl. Climatol., 49, 59-67, doi:10.1007/BF00868190, 1994.

Ben-Gai, T., Bitan, A., Manes, A., Alpert, P., and Rubin, S.: Spatial and Temporal Changes in Rainfall Frequency Distribution Patterns in Israel, Theor. Appl. Climatol., 61, 177-190, doi:10.1007/s007040050062, 1998.

Benzioni, A.: Jojoba Domestication and Commercialization in Israel, in: Horticultural Reviews, John Wiley \& Sons, Inc., 233266, doi:10.1002/9780470650585.ch7, 1995.
Benzioni, A.: Jojoba Domestication and Commercialization in Israel, in: Horticultural Reviews, Volume 17, edited by: Janick, J., John Wiley \& Sons, Inc., Oxford, UK, doi:10.1002/9780470650585.ch7, 2010.

Benzioni, A. and Dunstone, R. L.: Effect of air and soil temperature on water balance of jojoba growing under controlled conditions, Physiol. Plantarum, 74, 107-112, doi:10.1111/j.13993054.1988.tb04949.x, 1988.

Beringer, T., Lucht, W., and Schaphoff, S.: Bioenergy production potential of global biomass plantations under environmental and agricultural constraints, Global Change Biol. Bioenerg., 3, 299312, doi:10.1111/j.1757-1707.2010.01088.x, 2011.

Bonan, G. B.: Ecological climatology: concepts and applications, Cambridge University Press, available at: http://cabdirect.org/abstracts/20093323860.html;jsessionid= CECED55A707E2DDD7D339E29DF836BE4 (last access: 25 March 2014, 2008.

Burt, P. J. A.: Introduction to micrometeorology, Q. J. Roy. Meteorol. Soc., 128, 1039-1040, doi:10.1256/0035900021643665, 2002.

Chen, F. and Dudhia, J.: Coupling an Advanced Land SurfaceHydrology Model with the Penn State - NCAR MM5 Modeling System, Part I: Model Implementation and Sensitivity, Mon. Weather Rev., 129, 569-585. doi:10.1175/15200493(2001)129<0587:CAALSH>2.0.CO;2, 2001.

Choudhury, B. J. and DiGirolamo, N. E.: A biophysical processbased estimate of global land surface evaporation using satellite and ancillary data I. Model description and comparison with observations, J. Hydrol., 205, 164-185, 1998.

Dalu, G. A., Pielke, R. A., Baldi, M., and Zeng, X.: Heat and Momentum Fluxes Induced by Thermal Inhomogeneities with and without Large-Scale Flow, J. Atmos. Sci., 53, 3286-3302, 1996.

De Ridder, K. and Gallée, H.: Land surface-induced regional climate change in southern Israel, J. Appl. Meteorol., 37, 1470-1485, doi:10.1175/15200450(1998)037<1470:LSIRCC>2.0.CO;2, 1998.

Du, C., Wu, W., Liu, X., and Gao, W.: Simulation of Soil Moisture and Its Variability in East Asia, edited by: Gao, W. and Ustin, S. L., Soc. Photo-Opt. Instru. (SPIE) Conference Series, San Diego, California, USA, 62982F-62982F-6, 2006.

Dyer, A. J. and Hicks, B. B.: Flux-gradient relationships in the constant flux layer, Q. J. Roy. Meteorol. Soc., 96, 715-721, doi:10.1002/qj.49709641012, 1970.

Finnigan, J. J., Shaw, R. H., and Patton, E. G.: Turbulence structure above a vegetation canopy, J. Fluid Mech., 637, 387-424, 2009.

Fritzmann, C., Löwenberg, J., Wintgens, T., and Melin, T.: State-ofthe-art of reverse osmosis desalination, Desalination, 216, 1-76, doi:10.1016/j.desal.2006.12.00, 2007.

Hamilton, A. J., Stagnitti, F., Xiong, X., Kreidl, S. L., Benke, K. K., and Maher, P.: Wastewater Irrigation: The State of Play, Vadose Zone J., 6, 823-840, 2007.

Harding, K. J. and Snyder, P. K.: Modeling the Atmospheric Response to Irrigation in the Great Plains, Part I: General Impacts on Precipitation and the Energy Budget, J. Hydrometeorol., 13, 1667-1686, doi:10.1175/JHM-D-11-098.1, 2012.

Hong, S.-Y., Noh, Y., and Dudhia, J.: A New Vertical Diffusion Package with an Explicit Treatment of Entrainment Processes, Mon. Weather Rev., 134, 2318-2341, doi:10.1175/MWR3199.1, 2006. 
Hong, X.: Role of vegetation in generation of mesoscale circulation, Atmos. Environ., 29, 2163-2176, 1995.

Hu, X.-M., Nielsen-Gammon, J. W., and Zhang, F.: Evaluation of Three Planetary Boundary Layer Schemes in the WRF Model, J. Appl. Meteorol. Clim., 49, 1831-1844, doi:10.1175/2010JAMC2432.1, 2010.

Hussain, G., Bashir, M. A., and Ahmad, M.: Brackish water impact on growth of jojoba (Simmondsia chinensis), J. Agric. Res, 49, 591-596, 2011.

Iacono, M. J., Delamere, J. S., Mlawer, E. J., Shephard, M. W., Clough, S. A., and Collins, W. D.: Radiative forcing by long-lived greenhouse gases: Calculations with the AER radiative transfer models, J. Geophys. Res., 113, D13103, doi:10.1029/2008JD009944, 2008.

Ingwersen, J., Steffens, K., Högy, P., Warrach-Sagi, K., Zhunusbayeva, D., Poltoradnev, M., Gäbler, R., Wizemann, H.-D., Fangmeier, A., Wulfmeyer, V., and Streck, T.: Comparison of Noah simulations with eddy covariance and soil water measurements at a winter wheat stand, Agr. Forest Meteorol., 151, 345-355, 2011.

Khawaji, A. D., Kutubkhanah, I. K., and Wie, J.-M.: Advances in seawater desalination technologies, Desalination, 221, 47-69, doi:10.1016/j.desal.2007.01.067, 2008.

Kueppers, L. M., Snyder, M. A., and Sloan, L. C.: Irrigation cooling effect: Regional climate forcing by land-use change, Geophys. Res. Lett., 34, L03703, doi:10.1029/2006GL028679, 2007.

Letzel, M. O. and Raasch, S.: Large Eddy Simulation of Thermally Induced Oscillations in the Convective Boundary Layer, J. Atmos. Sci., 60, 2328-2341, doi:10.1175/15200469(2003)060\%3C2328\%3ALESOTI\%3E2.0.CO\%3B2, 2003.

Lim, Y.-J., Hong, J., and Lee, T.-Y.: Spin-up behavior of soil moisture content over East Asia in a land surface model, Meteorol. Atmos. Phys., 118, 151-161, doi:10.1007/s00703-012-0212-x, 2012.

Mahfouf, J. F., Evelyne, R., and Mascart, P.: The Influence of Soil and Vegetation on the Development of Mesoscale Circulations, J. Appl. Meteorol., 26, 1483-1495, 1987.

Mahrt, L. and Ek, M.: The Influence of Atmospheric Stability on Potential Evaporation, J. Clim. Appl. Meteorol., 23, 222-234, 1984.

Mlawer, E. J., Taubman, S. J., Brown, P. D., Iacono, M. J. and Clough, S. A.: Radiative transfer for inhomogeneous atmospheres: RRTM, a validated correlated-k model for the longwave, J. Geophys. Res., 102, 16663-16682, 1997.

Molthan, A. L. and Colle, B. A.: Comparisons of Single- and Double-Moment Microphysics Schemes in the Simulation of a Synoptic-Scale Snowfall Event, Mon. Weather Rev., 140, 29823002, doi:10.1175/MWR-D-11-00292.1, 2012.

Monteith, J.: Evaporation and environment, Symp. Soc. Exp. Biol., 19, 205-234, 1965.

Morrison, H. and Gettelman, A.: A New Two-Moment Bulk Stratiform Cloud Microphysics Scheme in the Community Atmosphere Model, Version 3 (CAM3), Part I: Description and Numerical Tests, J. Climate, 21,3642-3659, doi:10.1175/2008JCLI2105.1, 2008.

Niu, G., Rodriguez, D., Mendoza, M., Jifon, J., and Ganjegunte, G.: Responses of Jatropha curcas to Salt and Drought Stresses, Int. J. Agron., 2012, 1-7, doi:10.1155/2012/632026, 2012.
Oron, G., Campos, C., Gillerman, L., and Salgot, M.: Wastewater treatment, renovation and reuse for agricultural irrigation in small communities, Agr. Water Manage., 38, 223-234, doi:10.1016/S0378-3774(98)00066-3, 1999.

Otles, Z. and Gutowski, W. J.: Atmospheric Stability Effects on Penman-Monteith Evapotranspiration Estimates, Pure Appl. Geophys., 162, 2239-2254, doi:10.1007/s00024-005-2713-8, 2005.

Otterman, J.: Enhancement of surface-atmosphere fluxes by desertfringe vegetation through reduction of surface albedo and of soil heat flux, Theor. Appl. Climatol., 40, 67-79, 1989.

Otterman, J., Manes, A., Rubin, S., Alpert, P., and Starr, D. O.: An increase of early rains in Southern Israel following land-use change? Bound.-Lay. Meteorol., 53, 333-351, doi:10.1007/BF02186093, 1990.

Paulson, C. A.: The Mathematical Representation of Wind Speed and Temperature Profiles in the Unstable Atmospheric Surface Layer, J. Appl. Meteorol., 9, 857-861, doi:10.1175/15200450(1970)009<0857:TMROWS>2.0.CO;2, 1970.

Penman, H. L.: Natural Evaporation from Open Water, Bare Soil and Grass, P. Roy. Soc. A, 193, 120-145, 1948.

Perlin, N. and Alpert, P.: Effects of land use modification on potential increase of convection: A numerical mesoscale study over south Israel, J. Geophys. Res., 106, 22621-22634, 2001.

Pielke Sr., R. A.: Mesoscale meteorological modeling, 2nd Edn., Academic Press, San Diego, CA, 676 pp., 2002.

Qian, Y., Huang, M., Yang, B., and Berg, L. K.: A Modeling Study of Irrigation Effects on Surface Fluxes and Land-Air-Cloud Interactions in the Southern Great Plains, J. Hydrometeorol., 14, 700-721, doi:10.1175/JHM-D-12-0134.1, 2013.

Rajaona, A. M., Brueck, H., Seckinger, C., and Asch, F.: Effect of salinity on canopy water vapor conductance of young and 3-year old Jatropha curcas L., J. Arid Environ., 87, 35-41, 2012.

Rajaona, A., Brueck, H., and Asch, F.: Leaf Gas Exchange Characteristics of Jatropha as Affected by Nitrogen Supply, Leaf Age and Atmospheric Vapour Pressure Deficit, J. Agron. Crop Sci., 199, 144-153, doi:10.1111/jac.12000, 2013.

Raupach, M. and Finnigan, J.: Coherent eddies and turbulence in vegetation canopies: the mixing-layer analogy, Bound.-Lay. Meteorol., 78, 351-382, doi:10.1007/BF00120941, 1996.

Rotach, M. W., Ambrosetti, P., Apenzeller, C., Arpagus, M., Fontannaz, L., Fundel, F., Germann, U., Hering, A., Liniger, M. A., Stoll, M., Walser, A., Bauer, H.-S., Behrendt, A., Wulfmeyer, V., Bouttier, F., Seity, Y., Buzzi, A., Davolio, S., Carazza, M., Denhard, M., Dorniger, M., Gorgas, T., Frick, J., Hegg, C., Zappa, M., Keil, C., Volkert, H., Marsigli, C., Montaini, A., McTaggartCowan, R., Mylne, K., Ranzi, R., Richard, E., Rossa, A., SantosMuñoz, D., Schär, C., Staudinger, M., Wang, Y., and Werhahn, J.: MAP D-PHASE: Realtime Demonstration of Weather Forecast Quality in the Alpine Region, Bu. Am. Meteorol. Soc., 90, 1321-1336, 2009.

Rotach, M. W., Ambrosetti, P., Apenzeller, C., Arpagus, M., Fontannaz, L., Fundel, F., Germann, U., Hering, A., Liniger, M. A., Stoll, M., Walser, A., Bauer, H.-S., Behrendt, A., Wulfmeyer, V., Bouttier, F., Seity, Y., Buzzi, A., Davolio, S., Carazza, M., Denhard, M., Dorniger, M., Gorgas, T., Frick, J., Hegg, C., Zappa, M., Keil, C., Volkert, H., Marsigli, C., Montaini, A., McTaggartCowan, R., Mylne, K., Ranzi, R., Richard, E., Rossa, A., SantosMuñoz, D., Schär, C., Staudinger, M., Wang, Y., and Werhahn, 
J.: MAP D-PHASE: Real-Time Demonstration of Weather Forecast Quality in the Alpine Region, B. Am. Meteorol. Soc., 90, 1321-1336, doi:10.1175/2009BAMS2776.1, 2010.

Rotenberg, E. and Yakir, D.: Contribution of semi-arid forests to the climate system, Science, 327, 451-454, 2010.

Schwitalla, T., Bauer, H.-S., Wulfmeyer, V., and Zängl, G.: Systematic errors of QPF in low-mountain regions as revealed by MM5 simulations, Meteorol. Z., 17, 903-919, 2008.

Shin, H. H. and Hong, S.-Y.: Intercomparison of Planetary Boundary-Layer Parametrizations in the WRF Model for a Single Day from CASES-99, Bound.-Lay. Meteorol., 139, 261-281, doi:10.1007/s10546-010-9583-z, 2011.

Silva, E. N., Ribeiro, R. V., Ferreira-Silva, S. L., Viégas, R. A., and Silveira, J. A. G.: Comparative effects of salinity and water stress on photosynthesis, water relations and growth of Jatropha curcas plants, J. Arid Environ., 74, 1130-1137, 2010.

Spreer, W., Nagle, M., Neidhart, S., Carle, R., Ongprasert, S., Müller, J., and Muller, J.: Effect of regulated deficit irrigation and partial rootzone drying on the quality of mango fruits (Mangifera indica L., cv. "Chok Anan”), Agr. Water Manage., 88, 173-180, 2007.

Sridhar, V.: Tracking the Influence of Irrigation on Land Surface Fluxes and Boundary Layer Climatology, J. Contemp. Water Res. Educ., 152, 79-93, 2013.

Sumner, D. M. and Jacobs, J. M.: Utility of Penman-Monteith, Priestley-Taylor, reference evapotranspiration, and pan evaporation methods to estimate pasture evapotranspiration, J. Hydrol., 308, 81-104, doi:10.1016/j.jhydrol.2004.10.023, 2005.

Van Heerwaarden, C. C., Vilà-Guerau de Arellano, J., Moene, A. F., and Holtslag, A. A. M.: Interactions between dryair entrainment, surface evaporation and convective boundarylayer development, Q. J. Roy. Meteorol. Soc., 135, 1277-1291, doi:10.1002/qj.431, 2009.

Warner, T.: Desert Meteorology, Int. J. Climatol., 26, 1737-1738, doi:10.1002/joc.1347, 2006.

Webb, E. K.: Profile relationships: The log-linear range, and extension to strong stability, Q. J. Roy. Meteorol. Soc., 96, 67-90, doi:10.1002/qj.49709640708, 1970.

Weusthoff, T., Ament, F., Arpagaus, M., and Rotach, M. W.: Assessing the Benefits of Convection-Permitting Models by Neighborhood Verification: Examples from MAP D-PHASE, Mon. Weather Rev., 138, 3418-3433, doi:10.1175/2010MWR3380.1, 2010.
Warrach-Sagi, K., Schwitalla, T., Wulfmeyer, V., and Bauer, H.-S.: Evaluation of a climate simulation in Europe based on the WRFNOAH model system: precipitation in Germany, Clim. Dynam., 41, 755-774, doi:10.1007/s00382-013-1727-7, 2013.

Wulfmeyer, V., Behrendt, A., Bauer, H.-S., Kottmeier, C., Corsmeier, U., Blyth, A., Craig, G., Schumann, U., Hagen, M., Crewell, S., Di Girolamo, P., Flamant, C., Miller, M., Montani, A., Mobbs, S., Richard, E., Rotach, M. W., Arpagaus, M., Russchenberg, H., Schlüssel, P., König, M., Gärtner, V., Steinacker, R., Dorninger, M., Turner, D. D., Weckwerth, T., Hense, A., and Simmer, C.: The Convective and Orographically-induced Precipitation Study, B. Am. Meteorol. Soc., 89, 1477-1486, doi:10.1175/2008BAMS2367.1, 2008.

Wulfmeyer, V., Behrendt, A., Kottmeier, Ch., Corsmeier, U., Barthlott, C., Craig, G. C., Hagen, M., Althausen, D., Aoshima, F., Arpagaus, M., Bauer, H.-S., Bennett, L., Blyth, A., Brandau, C., Champollion, C., Crewell, S., Dick, G., Di Girolamo, P., Dorninger, M., Dufournet, Y., Eigenmann, R., Engelmann, R., Flamant, C., Foken, T., Gorgas, T., Grzeschik, M., Handwerker, J., Hauck, C., Höller, H., Junkermann, W., Kalthoff, N., Kiemle, C., Klink, S., König, M., Krauss, L., Long, C. N., Madonna, F., Mobbs, S., Neininger, B., Pal, S., Peters, G., Pigeon, G., Richard, E., Rotach, M. W., Russchenberg, H., Schwitalla, T., Smith, V., Steinacker, R., Trentmann, J., Turner, D. D., van Baelen, J., Vogt, S., Volkert, H., Weckwerth, T., Wernli, H., Wieser, A., and Wirth, M.: The Convective and Orographically Induced Precipitation Study (COPS): The Scientific Strategy, the Field Phase, and First Highlights, Q. J. Roy. Meteorol. Soc., 137, 330, doi:10.1002/qj.752, 2011.

Wulfmeyer, V., Branch, O., Warrach-Sagi, K., Bauer, H.-S., Schwitalla, T., and Becker, K.: The impact of plantations on weather and climate in coastal desert regions, J. Appl. Meteorol. Clim., doi:10.1175/JAMC-D-13-0208.1, in press, 2014.

Zhang, Y., Wang, X., Pan, Y., and Hu, R.: Diurnal and seasonal variations of surface albedo in a spring wheat field of arid lands of Northwestern China, Int. J. Biometeorol., 57, 67-73, 2013. 


\section{Appendix A}

\section{NOAH LSM ET}

The following expression based on a Penman-Monteith formulation is used by NOAH to calculate $\mathrm{ET}_{\mathrm{C}}$ (see e.g. Chen and Dudhia, 2001):

$$
\begin{aligned}
\mathrm{ET}_{\mathrm{C}} & =\underbrace{\left(\frac{\Delta\left(R_{\mathrm{n}}-G\right)}{L_{\mathrm{v}}(\Delta+1)}+\frac{\rho_{\mathrm{a}}\left(e_{\mathrm{s}}-e_{\mathrm{a}}\right)}{S(1+\Delta)}\right)}_{\text {Potential ET }}[\underbrace{\left(1-\sigma_{\mathrm{f}}\right) \frac{\Theta-\Theta_{\mathrm{w}}}{\Theta_{\mathrm{FC}}-\Theta_{\mathrm{w}}}}_{\text {Direct ET }} \\
& \left.+\sigma_{\mathrm{f}}(\underbrace{\left[\frac{w_{\mathrm{C}}}{\mu}\right]^{0.5}}_{\text {Wet canopy ET }}+[\underbrace{1-\left(\left[\frac{w_{\mathrm{C}}}{\mu}\right]^{0.5}\right) B_{\mathrm{C}}}_{\text {Dry canopy ET }}])\right] \text { (A1) }
\end{aligned}
$$

where $R_{\mathrm{n}}-G$ is the available radiation $\left(\mathrm{MJ} \mathrm{d}^{-1}\right), \Delta$ is the slope of saturation vapour pressure against temperature, $L_{\mathrm{V}}$ is the latent heat of vaporization $\left(\mathrm{J} \mathrm{kg}^{-1}\right), \rho_{\mathrm{a}}$ is surface air density $\left(\mathrm{kg} \mathrm{m}^{-3}\right), e_{\mathrm{s}}-e_{\mathrm{a}}$ is the VPD $(\mathrm{kPa}), S$ is a stability coefficient and represents $C_{q} U$, where $C_{q}$ is the turbulent exchange coefficient for water vapour, described by the Richardson number. $\Theta_{\mathrm{FC}}$ is the field capacity and $\Theta_{\mathrm{w}}$ is the wilting point. $W_{\mathrm{C}}$ is the intercepted canopy water content $\left(\mathrm{kg} \mathrm{m}^{-2}\right), \mu$ is the maximum canopy capacity $\left(\mathrm{kg} \mathrm{m}^{-2}\right)$ and $B_{\mathrm{C}}$ is a modifier, analogous to $K_{\mathrm{C}}$ in Penman FAO 56, used to calculate $\mathrm{ET}_{\mathrm{C}}$ from $\mathrm{ET}_{0}$ :
$B_{\mathrm{C}}=\frac{1+\frac{\Delta}{R_{\mathrm{r}}}}{1+R_{\mathrm{c}} C_{q}+\frac{\Delta}{R_{\mathrm{r}}}}$.

$R_{\mathrm{r}}=f\left(U, T, P, C_{\mathrm{h}}\right)$, and $R_{\mathrm{c}}$ is the canopy resistance. For $R_{\mathrm{c}} \mathrm{NOAH}$ uses the Jarvis-type scheme, also described in Chen and Dudhia (2001), for calculating $R_{\mathrm{C}}$ :

$R_{\mathrm{c}}=\frac{R_{\mathrm{c} \min }}{\mathrm{LAI}_{\mathrm{eff}} F 1 F 2 F 3 F 4}$

where $R_{\mathrm{c} \text { min }}$ is an empirical constant and $\mathrm{LAI}_{\text {eff }}$ is the effective leaf area index (generally $0.5 \times \mathrm{LAI}$ ). $F 1, F 2, F 3, F 4$ are coefficients representing the effect of radiation, air humidity, air temperature and soil moisture on $R_{\mathrm{c}}$ respectively. $F 3$, the temperature coefficient is given by $1-0.0016\left(T_{\text {ref }}-\right.$ $T)^{2}$ where $T_{\text {ref }}$ is an optimum temperature for maximum photosynthesis and $F 4$, the soil moisture factor is given by the layer discretized expression:

$F 4=\sum_{i=1}^{\text {nroot }} \frac{\Theta-\Theta_{\mathrm{w}}}{\Theta_{\mathrm{FC}}-\Theta_{\mathrm{w}}} f_{\text {root }}$

where "nroot" is the number of soil layers where roots are present and $f_{\text {root }}$ is the layer's fraction of the root zone. 


\section{Appendix B}

\section{Field ET estimation methods}

There are standard methods used to estimate ET from vegetated surfaces, including so called Penman-Monteith methods (Penman, 1948; Monteith, 1965). Since Penman developed a method to estimate ET from an open water surface, others included evaporation estimates from other surfaces like canopies by incorporating various resistance terms. Further research includes the effects of different stability regimes - for instance, Mahrt and Ek (1984) and Otles and Gutowski (2005). Different methods have been devised and are used depending on (a) data availability, (b) required interval for averaging, e.g. daily/hourly; and (c) what assumptions can be made, e.g. stability.

\section{B1 Penman-Monteith $R_{\mathrm{a}} / \boldsymbol{R}_{\mathrm{s}}$ equation (Monteith, 1965)}

The following expression is the Penman-Monteith (Penman $R_{\mathrm{a}} / R_{\mathrm{s}}$ ) equation formulated to account for explicit surfaces and aerodynamic resistances:

$\operatorname{ET}_{\mathrm{C}}=\frac{\Delta\left(R_{\mathrm{n}}-G\right)}{L_{\mathrm{v}}(\Delta+1)}+\frac{\rho_{\mathrm{a}} C_{\mathrm{p}} \frac{\left(e_{\mathrm{s}}-e_{\mathrm{a}}\right)}{R_{\mathrm{a}}}}{\Delta+\gamma\left(1+\frac{R_{\mathrm{s}}}{R_{\mathrm{a}}}\right)}$

where $\mathrm{ET}_{\mathrm{C}}$ is the crop ET $\left(\mathrm{mm} \mathrm{d}^{-1}\right), C_{\mathrm{p}}$ is the specific heat of air at constant pressure $\left(\mathrm{J} \mathrm{Kg}^{-1} \mathrm{~K}^{-1}, \gamma\right.$ is the psychrometric constant $\left[\mathrm{kPa}^{\circ} \mathrm{K}^{-1}\right], R_{\mathrm{S}}$ and $R_{\mathrm{a}}$ are the surface and aerodynamic resistances respectively $\left(\mathrm{s} \mathrm{m}^{-1}\right)$. The resistance terms are defined respectively as

$$
\begin{aligned}
R_{\mathrm{S}} & =\frac{R_{l}}{\mathrm{LAI}_{\mathrm{eff}}} \\
R_{\mathrm{a}} & =\frac{\ln \left(\frac{Z-d}{Z_{0 \mathrm{~m}}}\right) \ln \left(\frac{Z-d}{Z_{0 \mathrm{~h}}}\right)}{k^{2} U_{z}}
\end{aligned}
$$

where $R_{l}$ represents the bulk stomatal resistance. In the second expression, $Z$ is the standard measurement height, $Z_{0 \mathrm{~m}}$ is the roughness height for momentum, $d$ is the displacement height, $Z_{0 \mathrm{~h}}$ is the roughness height for water vapour and $k$ is von Kármán's constant. Estimations for $d, Z_{0 \mathrm{~m}}, Z_{0 \mathrm{~m}}$ have been suggested (Allen et al., 1998), assuming that roughness heights for vapour and heat are equivalent:

$d=2 / 3 h$

$Z_{\mathrm{om}}=0.123 h$

$Z_{\mathrm{oh}}=0.1 Z_{\mathrm{om}}$

where $h$ is the height of the canopy. In order to use this method, values for bulk stomatal resistances $\left(R_{l}\right)$ are a prerequisite. Estimations for Jojoba resistances under different conditions were collated for the report of the Seventh Conference on Jojoba (1988) and are shown in Table B1.
Table B1. Measurements of the stomatal resistances of Jojoba using different methods, at different times of day; and under varying moisture and salinity conditions. Taken from the Seventh International Conference on Jojoba and Its Uses: Proceedings (1988). See the text for individual references.

\begin{tabular}{lll}
\hline Method & Conditions & $\begin{array}{l}\text { Stomatal } \\
\text { resistance } \\
\left(\mathrm{s} \mathrm{m}^{-1}\right)\end{array}$ \\
\hline \begin{tabular}{lll} 
Heavy water scintillation & Well watered, low salt & 333.3 \\
Diffusive resistance & Well watered, low salt & 625 \\
Diffusive resistance & Well watered, high salt & 1666 \\
$\begin{array}{l}\text { Diffusion porometer } \\
\text { Diffusion porometer }\end{array}$ & Well watered, January & 250 \\
Continuous flow & Well watered, June & 312.5 \\
Continuous flow & Well watered, 07:00 LT & 250 \\
Unknown & Well watered, 11:00 LT & 500 \\
\hline
\end{tabular} Well watered, median & 312 \\
\hline
\end{tabular}

From these estimates it can be deduced that mean $R_{l}$ values of between 300 and 650 seem feasible for well-watered plants in summertime. The difference in early morning resistance $\left(250 \mathrm{~s} \mathrm{~m}^{-1}\right)$ compared to 11:00 LT $\left(500 \mathrm{~s} \mathrm{~m}^{-1}\right)$ reflects a common desert plant strategy of closing the stomata during the hotter parts of the day. Another factor when choosing a suitable $R_{l}$ value is that in reality, although the plants are watered adequately, only the minimum amount needed for plant health and optimized yields, are fed to the plants. In arid regions, even with slightly compromised yields, Jojoba production could still be optimal if the savings in water costs exceed the opportunity costs conceded due to lower yields. Lower inputs would indicate higher $R_{l}$ values. In other words, under greater water stress it is reasonable to expect higher values of $R_{l}$. Regarding the effect of salinity on stomatal resistance, extremely high $R_{l}$ values are estimated for salt-sensitive plants in saline soils, even exceeding $1000 \mathrm{~s} \mathrm{~m}^{-1}$. Given the mean values of $1 \mathrm{dS} \mathrm{m}^{-1}$ quoted for the irrigation water it is likely that only a minimum of leaching by winter rains may be needed to avoid salt accumulation. The FAO (Ayers and Westcott, 1985) quote one method for estimating the annual water requirement for leaching as $A_{\mathrm{w}}=\mathrm{ET}(1-\mathrm{LR})$, where $A_{\mathrm{w}}$ is the annual water requirement including irrigation and ET is the annual irrigation applied. LR is a coefficient for the minimum leaching requirement needed to control salts within the tolerance of the crop. This is calculated as $\mathrm{LR}=\mathrm{EC}_{\mathrm{w}} /\left(5 \mathrm{EC}_{\mathrm{e}}-\mathrm{EC}_{\mathrm{w}}\right)$, where $\mathrm{EC}_{\mathrm{w}}$ is the salinity of the applied irrigation water in $\mathrm{dS} \mathrm{m}^{-1}$. $\mathrm{EC}_{\mathrm{e}}$ is the average soil salinity tolerated by the crop as measured on a soil saturation extract. The FAO recommends that the tolerance value used should represent a maximum of $90 \%$ reduction of the potential yield, but $100 \%$ for moderate to heavy salinity $\left(>1.5 \mathrm{dS} \mathrm{m}^{-1}\right)$. Only sparse data on Jojoba salt tolerance is available and many factors could complicate estimates, such as plant varieties and age. Hussein et al. (2011) reported that young Jojoba plants can withstand up to $8 \mathrm{dS} \mathrm{m}^{-1}$, with one variety "Siloh" tolerating $10 \mathrm{dS} \mathrm{m}^{-1}$ 
with no reduction in flower production. However these are juvenile plants or seedlings. They also state that salt tolerance increases with the age and vigour of the plants. If we insert a value of $8 \mathrm{dS} \mathrm{m}^{-1}$ and an annual ET of $700 \mathrm{~mm}$ for Jojoba, this yields a leaching requirement of $20 \mathrm{~mm}$. If we are more conservative and choose a tolerance of $2 \mathrm{dS} \mathrm{m}^{-1}$ (as estimated in Ayers and Westcott, 1985 for sorghum, grapefruit and orange trees), and assuming a maximum $10 \%$ yield reduction this would require around $90 \mathrm{~mm}$. Therefore, it is safe to assume that any accumulated salt is leached by the $200 \mathrm{~mm}$ of winter rain which is average for Be'ér Sheva'. Anecdotally, the managers report that there has been no significant soil degradation due to salinization, even dating back to 1948 when the first plantations were implemented. In spite of this, it is apparent that at least some salt is present in the soils during summer, and this is evident from small patches of salt accruing where water has occasionally breached the surface. Given the very high sensitivity of Jojoba stomatal resistance to salt stress (Table B1), it was thought to be safer to assume a small amount of salt stress. Therefore, a corresponding value of $800 \mathrm{~s} \mathrm{~m}^{-1}$ was estimated for $R_{l}$. This higher value can also be justified by the deficit irrigation technique which is associated with higher resistances when compared with cruder methods, e.g. surface irrigation. In this regard, stomatal resistances could also exhibit a diurnal peak during the afternoon when soil water around the roots becomes depleted, and soil water is redistributed at night.

Mean seasonal hourly values calculated from this Penman method were multiplied by the vegetated fraction $\left(\sigma_{\mathrm{f}}\right)$ estimated at $70 \%$.

\section{B2 FAO-56 Penman-Monteith Equation (Allen, 1998)}

The following expression is the Penman-Monteith equation (FAO-56) using a crop coefficient $K_{\mathrm{c}}$ to modify $\mathrm{ET}_{0}$ (Eq. B7):

$$
\mathrm{ET}_{0}=\frac{0.408 \Delta\left(R_{\mathrm{n}}-G\right)+\gamma\left(\frac{900(\mathrm{~K})}{T\left({ }^{\circ} \mathrm{C}\right)+273.16}\right) \frac{u_{z}\left(\mathrm{~ms}^{-1}\right)}{\mathrm{ms}^{-1}}\left(e_{\mathrm{s}}-e_{\mathrm{a}}\right)}{\Delta+\gamma\left(0.34 u_{z}\left(\mathrm{~m} \mathrm{~s}^{-1}\right)+1 \mathrm{~m} \mathrm{~s}^{-1}\right)}
$$

where $\mathrm{ET}_{0}$ is the reference evapotranspiration $\left(\mathrm{mm} \mathrm{d}^{-1}\right)$ of a well-irrigated cut grass crop, $R_{\mathrm{n}}-G$ is the net available radiation $\left(\mathrm{MJ} \mathrm{d}^{-1}\right), T$ is temperature at standard height $\left({ }^{\circ} \mathrm{C}\right)$ and $u_{z}$ is the wind speed at standard height $\left(\mathrm{m} \mathrm{s}^{-1}\right) . \mathrm{ET}_{\mathrm{c}}$ is modified using $K_{\mathrm{C}}$ i.e. $\mathrm{ET}_{\mathrm{c}}=\mathrm{ET}_{0} \times \sigma_{\mathrm{f}} \times K_{\mathrm{c}}$, where $\mathrm{ET}_{\mathrm{c}}$ represents the actual crop ET estimate. In general terms the $\mathrm{ET}_{0}$ can be thought of as the first-order climatic demand and $K_{\mathrm{C}}$ is a modifier. $K_{\mathrm{C}}$ accounts for species-specific physiological and physical factors, differentiating the crop from the reference vegetation and is intended to represent the effect of: crop type, albedo, stomatal resistance and direct soil evaporation. It is the ratio of $\mathrm{ET}_{0}$ to the $\mathrm{ET}_{\mathrm{c}}$ and is often $<1$, but not in all cases. With closely-spaced, tall, freelytranspiring canopies, $K_{\mathrm{C}}$ can be as much as 15 to $20 \%>1$. A dual $K_{\mathrm{C}}$ method can also be used by splitting the coefficient $K_{\mathrm{C}}$ into basal crop and soil evaporation components
$\left(K_{\mathrm{CB}}+K_{\mathrm{E}}\right)$. However, since we assume negligible soil evaporation with sub-surface irrigation, $K_{\mathrm{E}}$ would be negligible. We therefore concentrate on the basal effect only i.e. a single $K_{\mathrm{C}}$ value. Normally $K_{\mathrm{C}}$ values are available in lookup tables made available by the FAO but specific values for Jatropha and Jojoba are not given, so values were substituted from the nearest crop type in terms of height, biomass, geographical distribution and characteristics (oil seed crops and fruit tree categories). The validity of doing this is of course debateable. For nearly the whole year, a value of 0.7 is estimated by the FAO for these categories (this falls fractionally to 0.65 in the coolest winter months). Another source gives Jojoba a value of 0.5 all year round (Benzioni and Dunstone, 1998). A constant value is a reasonable assumption in arid regions, especially for the Israel Jojoba plants because they are fully mature perennials whose shape is maintained by periodic pruning. This contrasts with some crops such as annuals whose $K_{\mathrm{C}}$ varies widely over phenological stages.

It should be noted that when conditions are calm and humid, the aerodynamic factors of tall, dense canopies have less effect on the $\mathrm{ET}_{0} / \mathrm{ET}_{\mathrm{c}}$ ratio than the radiation which is the dominating driver of ET at low wind speeds. When relative humidities are lower than $45 \%$ (assumed in the reference $K_{\mathrm{C}}$ estimates) the vapour pressure deficit (VPD) is higher, and the aerodynamics of taller crops has more effect. This can be better seen from the ratio $\left(e_{\mathrm{s}}-e_{\mathrm{a}}\right) R_{\mathrm{a}}^{-1}$ in the numerator of Penman, $R_{\mathrm{a}} / R_{\mathrm{S}}$ (Eq. $\mathrm{B} 1$ ). In arid conditions when the VPD is high, the ratio will be larger, which means that a significant change in $R_{\mathrm{a}}$ will have a large effect on the $\mathrm{ET}_{0}$. Accordingly, the differences in $\mathrm{ET}_{0}$ estimation would be amplified with tall crops experiencing higher wind speeds because the aerodynamic term is proportional to $U_{z}$ and canopy height. Over the plantations, mean minimum daytime RH values are $29.6 \%$ over the Jatropha and $30.0 \%$ over the Jojoba which represents a large VPD. However the mean daytime wind speeds are low $\left(1.71 \mathrm{~m} \mathrm{~s}^{-1}\right.$ Jatropha and $1.88 \mathrm{~m} \mathrm{~s}^{-1}$ Jojoba) which would likely be a compensating factor. This was checked by using an adjustment modifier for mid-season $K_{\mathrm{C}}$ from Allen et al. (1998) (Eq. B8):

$$
\begin{aligned}
K_{\mathrm{C}} & =K_{\mathrm{C}}(\text { Table })+\left[0.04\left(\frac{\overline{U_{Z}}\left(\mathrm{~m} \mathrm{~s}^{-1}\right)-2 \mathrm{~m} \mathrm{~s}^{-1}}{\mathrm{~m} \mathrm{~s}^{-1}}\right)\right. \\
& \left.-0.004\left(\frac{\mathrm{RH}_{\min }-45 \%}{\%}\right)\left(\frac{h}{3 m}\right)^{0.3}\right]
\end{aligned}
$$

where $\overline{u_{Z}}$ is the mean $2 \mathrm{~m}$ daytime wind speed $\left(\mathrm{m}^{-1}\right)$ and RH is the minimum daytime relative humidity $(\%)$. Using this correction and the observation data, the $K_{\mathrm{C}}$ value remains virtually unchanged because the low RH is offset by low wind speeds. Therefore the $K_{\mathrm{C}}$ values used were not changed for the calculations.

There are other factors which may affect ET, such as crop and leaf geometry to name just two examples. Regarding geometry, in Jojoba the leaf orientation is almost vertical which, 
as well as affecting the turbulent wind characteristics, would also reduce incident solar radiation on the leaves when the solar zenith angle is low and temperatures are at their highest. Transpiration and photosynthesis rates tend to be correlated with solar radiation intensity. This would therefore minimize evaporation and heat loading at midday and optimize photosynthesis, when heat and water potential losses are low (Seventh International Conference on Jojoba and Its Uses: Proceedings, 1988). Factors such as these are difficult to take into account within a general $K_{\mathrm{C}}$ coefficient however but further research to improve species-specific estimates are out of the scope of this study. 


\section{Appendix C}

\section{Wind observation height extrapolation}

The wind data $(6 \mathrm{~m})$ was extrapolated to a standard $10 \mathrm{~m}$ height using the following standard neutral stability log profile law (WMO):

$$
\frac{\overline{U_{1}}}{U_{\text {ref }}}=\ln \left(\frac{Z_{1}-d}{Z_{0 \mathrm{~m}}}\right) / \ln \left(\frac{Z_{\text {ref }}}{Z_{0 \mathrm{~m}}}\right)
$$

where $\overline{U_{1}}$ is the wind speed at measurement height, $U_{\text {ref }}$ is the wind speed at the standard height of $10 \mathrm{~m}, Z_{1}$ is the height of the wind sensor, $Z_{\text {ref }}$ is the standard height $(10 \mathrm{~m}), d$ is the displacement height (Eq. B4) and $Z_{0 \mathrm{~m}}$ is the roughness length for momentum (Eq. B5). For Desert and Jojoba, values of $0 \mathrm{~m}$ and $2 \mathrm{~m}(2 / 3 h)$ were used for $d$ and $0.0005 \mathrm{~m}$ and $0.369 \mathrm{~m}(0.123 h)$ for $Z_{0 \mathrm{~m}}$, respectively. 